\title{
IMPROVEMENT THE RELEASE AND AVAIALBILITY OF CELECOXIB CO-ADSORBATE FROM FLOATING CAPSULES
}

\author{
Sherif K. Abu-elyazid*, Alaa K.*, Ahmed M. S*, Eman M. Samy** and Yasser A. Hassan \\ *Pharmaceutics and Industrial Pharmacy Deptartment, Faculty of Pharmacy-(Boys) - Al- \\ Azhar University, Cairo, Egypt. \\ **Industrial Pharmacy Deptartment, Faculty of Pharmacy- Assuit University, Assuit, Egypt.
}

\begin{abstract}
Celecoxib is a selective COX-2 inhibitor non-steroidal anti-inflammatory drug (NSAID) used in the treatment of osteoarthritis, rheumatoid arthritis, and to reduce numbers of colon and rectum polyps in patients with familial adenomatous polyposis. Celecoxib is practically inslouble in GIT $\mathrm{pH}$. Consequently, it suffers from low and variable bioavailability following oral administration of solutions (64-88\%) and capsules (20-40\%)
\end{abstract}

In the present study, gastroretentive controlled release single-unit floating capsules of Celecoxib were designed and evaluated. Various grades of low and high viscosity polymers of HPMC 4000 and $15.000 \mathrm{cps}$ and $\mathrm{NaCMC}$ were used for formulation of Celecoxib capsules.

For the purpose of enhancing the poor dissolution rate of Celecoxib, co-adsorption with Tween 80 onto surface of Florite ${ }^{\circledR}$ was investigated in this study. Thus, controlled release limited by drug solubility was percluded and delivery of active material was controlled by the formulation. In the present study conventional capsules containing Celecoxib using HPMC and NaCMC were developed and evaluated. Floating capsules containing Celecoxib, co-adsorption with Tween 80 onto surface of Florite and Aerosil 200 in different ratios were also formulated and investigated for the release of the drug from these capsules. The results obtained of this study showed that Celecoxib capsules containing HPMC $15000 \mathrm{cps}$ as a swelling matrix has a good floating behaviour and retarding effect on the drug release. Also, different concentrations of sodium bicarbonate confirmed and maintained the floating properties of the prepared formulations without affecting the drug release. From DSC and X-ray diffraction studies it was found that crystalline Celecoxib was converted into the amorphous form in the presence of Florite ${ }^{\circledR}$ at $(1: 5 \mathrm{w} / \mathrm{w}$ drug: carrier ratio) in the adsorbate and co-adsorbate with Tween 80 . The loaded and ground mixtures of Celecoxib with either Florite ${ }^{\circledR}$ or Aerosil 200 increased the dissolution rate of the drug. Furthermore, co-adsorbate of the drug with Florite ${ }^{\circledR}$ and Tween 80 at these ratios of (1:5:3 and 1:5:5) gave the highest percentage released of Celecoxib (reached about 100\% at 30 and 45 min., respectively).

\section{INTRODUCTION}

For the past three decades, oral controlled release dosage forms have been developed due to their important therapeutic advantages. By the introduction of a variety of controlled delivery systems, the inconvenience of conventional tablets or capsules that resulted in a transient overdose, followed by a long period of dosing was overcome. One of these delivery systems is the gastroretentive drug delivery systems (GRDDSs).

Besides being able to continually and sustainedly deliver drugs to the small intestinal absorption window, the improvements provided from GRDDSs include: achieving a greater and prolonged therapeutic effect and thus reducing the frequency of administration periods, providing a more effective treatment of local stomach disorders, and minimizing both lowertract inactivation of the drug and drug effects on the lower intestinal flora (Berner and Louie- Helm, 2002; Shell et al., 2003). Since that, various approaches such as floating 
(Iannuccelli et al., 1998; Streubel et al., 2002), bioadhesive (Preda and Leucuta, 2003), and swelling and expanding (Chen $\boldsymbol{e t}$ al., 2000; Chen and Park, 2000a,b; Zuleger and Lippold, 2001; Zuelger et al., 2002; Klausner et al., 2002, 2003; Torre and Torrado, 2003; Torrado et al., 2004; Torre et al., 2005) systems have been developed to increase the gastric retention time of a dosage form.

The above-mentioned approaches for gastrointestinal retention work by one or more of these mechanisms. The major challenge for a bioadhesive system is the high turnover rate of gastric mucus. Recent improvements in the field of size-increasing (swelling/expanding) drug delivery systems led to devices that caneasily be swallowed but rapidly increase in size once they reach the stomach, assuring prolonged gastric residence times. More importantly, their performance is independent of the filling state of the stomach and, after predetermined time intervals, they break into smaller pieces, guaranteeing their removal from the stomach. In contrast, the performance of low density, floating drug delivery systems is strongly dependent upon the filling state of the stomach (Streubel et al., 2006b). Various systems thus combining different gastroretentive mechanisms were developed to enhance gastroretention capabilities. Floating and bioadhesion to achieve retention have been combined in tablets consisting of blends of HPMC and Carbopol (Nur and Zhang, 2000) and tablets containing sotalol $\mathrm{HCl}$, sodium carboxymethyl cellulose (as the bioadhesive polymer), HPC (as the matrix-forming polymer), and carbonate (as the gas generator) (Jiménez-Castellanos et al., 1994).

Effervescent tablets with bioadhesive capabilities for ciprofloxacin were made of sodium carboxymethyl cellulose, HPMC, polyacrylic acid, polymethacrylic acid, citric acid, and sodium bicarbonate to lengthen the stay in the absorption region (Varshosaz et al., 2006). Metformin $\mathrm{HCl}$ was formulated as a floating (buoyant) matrix tablet using a gasgenerating agent (sodium carbonate) and a gel forming hydrophilic polymer (HPMC) showing a floating time of more than $8 \mathrm{~h}$ and promising drug release results (Basak et al., 2007).

A new sustained gastroretentive release delivery system was developed with floating (sodium bicarbonate), swellable (crospovidone and betacyclodextrin), and bioadhesive (psyllium husk and HPMC) properties of ofloxacin (Chavanpatil et al., 2006). A simple addition of sodium bicarbonate to the gel matrix-forming floating tablets made of HPMC and captopril was characterized by increased hydration volume and buoyancy (Jiménez-Martnez et al., 2008). Kollidon ${ }^{\circledR}$ SR (due to its low density) and sodium bicarbonate were added to compensate for the deficient floating properties of propranolol $\mathrm{HCl}$ in the preparation of directly compressible GRDDS (Strübing et al., 2008a, b).

Swellable, floating, and sustained release tablets developed by using a combination of hydrophilic polymer (HPMC), swelling agents (crospovidone, sodium starch glycolate, and croscarmelose sodium), and an effervescent substance (sodium bicarbonate) were found to show good swelling, drug release, and floating characteristics than CIFRAN OD® of which swellability of hydrophilic polymer was the main mechanism of gastroretention (Arza $\boldsymbol{e t}$ al., 2009). In this preliminary study, it was found that hydrocolloid tablets made of PEO $8,000 \mathrm{~K}$ had the largest swelling index, followed by hydroxyethyl cellulose (HEC), and the least for sodium carboxymethyl cellulose (NaCMC, $450 \mathrm{cps}$ or $2500 \mathrm{cps}$ ). However, the floating ability of these three polymeric materials was in the following order, HEC > NaCMC > PEO $8,000 \mathrm{~K}$, with the last material sinking to the bottom. Since both swelling/expanding to a larger size and floating in gastric fluid could extend stomach retention, it was thought that simply incorporating $\mathrm{NaCMC}$ in the matrix of HEC might synergistically enhance gastroretentive ability.

GRDDS was designed to prolong gastric residence time and provide for enhanced low bioavailability of Losartan relative to an equal dose of an immediate-release formulation 
through development of a swellable and floatable GRDDS based on a combination of sodium carboxymethyl cellulose (NaCMC) in hydroxyethyl cellulose (HEC) for Losartan (Sica et al., 2005; Lee et al., 2003).

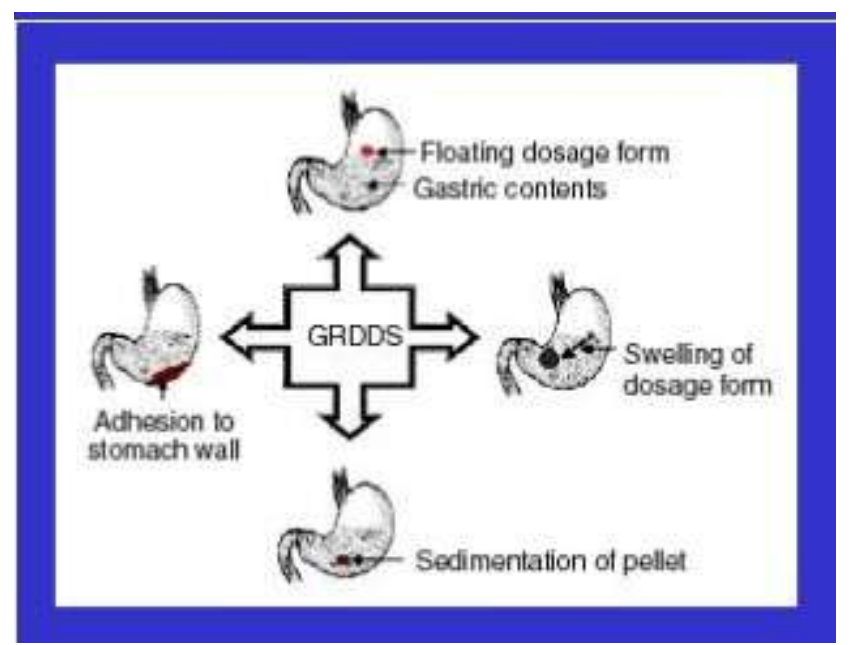

Figure (I): Different approaches of GRDDS

Garg and Gupta, classified the gastroretentive dosage forms into four main classes (Garg, and Gupta 2008): (i) floating systems (Xiaoqiang et al., 2006; Singha and Kim 2003), (ii) expandable systems (Deshpande et al., 1997), (iii) bioadhesive systems (Chavanpatil $\boldsymbol{e t}$ al., 2006), and (iv) high density systems (Hwang $\boldsymbol{e t}$ al., 1998; Chawla $\boldsymbol{e t}$ al., 2003). Floating systems are of two types: (A) effervescent systems, depending on the generation of carbon dioxide gas upon contact with gastric fluids, and non-effervescent systems.

As suggested by Singh and Kim (B.M. Singh and Kim 2000), floating drug delivery is of particular interest for drugs which: (a) act locally in the stomach such as Ciprofloxacin hydrochloride (Arza et al., 2009; Srinatha and Pandit, 2008; Srinath and Pandit, 2006; Sahoo et al., 2007); (b) are primarily absorbed in the stomach (Varshosaz et al., 2006); (c) are poorly soluble at an alkaline $\mathrm{pH}$; (d) have a narrow window of absorption (Arza et al., 2009; Sato et al., 2004); (e) are unstable in the intestinal or colonic environment such as captopril (Jain et al., 2005); and (f) for drugs that exhibit poor solubility in the intestinal tract such as diazepam and verapamil $\mathrm{HCl}$ (Wurster et al., 2003; Munday 2003).

Surface Adsorption

When poorly water-soluble drugs are administered in solid dosage forms, the dissolution rate is often considered as a rate-limiting factor in the absorption process. The rate of dissolution of these drugs depends upon the effective surface area and the energy state within the drug crystals (Shaker et al., 1992). Various techniques have been used to reduce particle size and, hence, increase surface area. These include freeze-drying (Chacon $\boldsymbol{e t}$ al., 1999), spray drying (Sato et al., 1981), and preparation of solid dispersions and molecular dispersions with certain hydrophilic carriers (Abdel-Rhaman et al., 1989; Hong et al., 1998).

Adsorption of drugs onto surfaces of inert matrices has been widely employed to reduce particle size of the drug by increasing the effective surface area available for dissolution. The technique of surface adsorption was first reported by Monkhouse and Lach (Mankhouse and Lach 1972). Florite ${ }^{\circledR}$ (porous calcium silicate, $2 \mathrm{CaO} 3 \mathrm{SiO}_{2}, \mathrm{nH}_{2} \mathrm{O}$ ), which has a characteristic porous structure and very low density, has been used for the development of an intragastric floating and sustained-release preparation. The floating ability of Florite ${ }^{\circledR}$ results from the air trapped in the porous structure of calcium silicate (Yuassa, et al., 1996). 


\section{Ad-Solubilization (Co-Adsorption)}

The use of surface-active agents as effective solubilizing aids in solid dosage forms is limited by their physico-chemical properties, as the majority of water soluble surfactants exist as viscous liquids or waxy solids at ambient temperatures. For obvious reasons, such materials are generally not conductive to the formulation and manufacture of traditional pharmaceutical tablets and capsules (Ruddy et al., 1999).

Surface-active agents may be adsorbed at solid hydrophilic interfaces forming various types of aggregates such as admicelles or bilayers depending upon the characteristics of the solid surface and surfactant, as well as, the physico-chemical conditions of the system in terms of $\mathrm{pH}$ and ionic strength. These surfactant aggregates may incorporate drug molecules which otherwise would not adsorb spontaneously onto the solid surface (Cherkaoui et al., 2000).

This phenomenon has been termed co-adsorption (Monticone and Treiner 1995) or ad-solubilization to emphasize that it concerns surfactants adsorbed at solid-liquid interfaces. In ad-solubilization, drug molecules are incorporated by a mechanism very similar to both ion-exchange and solubilization processes as it occurs in the classical micellar solutions (Cherkaoui et al., 2000). However, as the surfactant concentration is increased above the critical micelle concentration $(\mathrm{cmc})$ and the solid surface becomes saturated, free micelles must form. Therefore, equilibrium will be established between the fraction of the solute adsorbed at the solid interface and the fraction that is solubilized in the free micelles (Monticone and Treiner 1995).

Many investigations have been made particular emphasis on the importance of surface modification by surfactants for the incorporation of various drugs. For example, using other solid substrates such as alumina, acrylic matrices, albumin, and cyanoacrylate nanoparticles (Cherkaoui et al., 2000).

Celecoxib is practically inslouble in GIT pH. Consequently, it suffers from low and variable bioavailability following oral administration of solutions (64-88\%) or capsules (2040\%) (Paulson et al., 2001). It was reported by Paulson et al. (2001) that if the gastrointestinal transit time of Celecoxib could be prolonged, its absorption could be enhanced. So, the main objective of this article was to develop a hydrodynamically balanced system for Celecoxib as a single-unit floating capsules.

In an attempt to enhance the dissolution rate of Celecoxib, adosrbates and coadsorbates of the drug were prepared using different adsorbents e.g., Aerosil and Florite ${ }^{\circledR}$ in the presence of polysorbate 80 , then formulated in floated capsules to investigate the effect of these additives on the floating behavior and drug release.

\section{Materials:}

Celecoxib was obtained as a gift from Sedico Company (Egypt), Hydroxypropyl methyl cellulose, HPMC 4000cps and Sodium carboxymethly cellulose, NaCMC were supplied from Aldrich Chemicals Co., USA, Anhydrous lactose, Shefield chemical, N.J., USA, Magnesium stearate and sodium bicarbonate were obtained from El-Nasr Pharmaceutical Chemicals Co., Egypt, Transparent hard gelatin capsules (size 000), were kindly supplied by T3A Pharmaceutical Company, Assiut (Egypt), Porous calcium silicate (Florite $\left.{ }^{\circledR}\right)$ was obtained from Tokuyama soda co, Japan, Colloidal silicon dioxide (Aerosil 200), (Degussa Frankfurt, Germany), Polysorbate (Tween 80) was purchased from BDH Chemicals Ltd., Poole (England).

\section{Equipments:}

Differential Scanning Calorimetry, DSC-50 and FTIR- Spectrophotometer, IR-470 (Shimadzu, Japan), Single Punch Tablet Machine, Korsch-Berlin, EK/0, Franckfort 
(Germany), Erweka tablet hardness tester, Type TAB, Erweka tablet disintegration apparatus and Erweka friabilator apparatus, G.m.b.H. (Germany), Micrometer, Mitutoyo Corporation (Japan), Dissolution apparatus Dissolution apparatus (Hanson Researches- California USA), UV-160 IPC UV-Visible spectrophotometer (Shimadzu, Japan), Vibrating uniball mill (VEB leuchtenbou-KMI, Germany), Differential scanning calorimeter (DSC-Tso-Shimadzu, Japan). SPT-200 Vacuum Oven drier, Poland- X- Ray diffractometer (Philips 1710 diffractometer, Germany)

\section{Methodology}

\section{Conventional Floating Capsules}

\section{1- Preparation of Celecoxib Conventional Floating Capsules}

Celecoxib powder $(25 \mathrm{mg})$ was used for the preparation of floating capsules. HPMC 4000, HPMC 15000, sodium bicarbonate, and CMC sodium were used in different concentrations. Magnesium stearate was added in the concentration of $1 \% \mathrm{w} / \mathrm{w}$ as a lubricant, while anhydrous lactose was used as a diluent to obtain the desired weight of each capsule.

The calculated amount of each ingredient was mixed in a suitable dish till a homogenous mixture was obtained. The powder blend was then placed in a horizontal plate. Hard gelatin capsules were filled manually by bunching the capsule body against the powder sheet. The weight of each filled capsule was adjusted to the required weight $150 \mathrm{mg}$. The different prepared formulae of Celecoxib floating capsules were taken the symbols of FC1 FC12 as it was shown in table (1).

Table (1): Composition of the Prepared Conventional Celecoxib Floating Capsule Formulations

\begin{tabular}{|c|c|c|c|c|c|c|c|c|c|c|c|c|}
\hline Formula & Amo & int of & ngred & ents u & ed in & $\operatorname{ach}$ fo & mula & mg) & & & & \\
\hline & FC1 & FC2 & FC3 & FC4 & FC5 & FC6 & FC7 & FC8 & FC9 & FC10 & FC11 & FC12 \\
\hline Celecoxib & 25 & 25 & 25 & 25 & 25 & 25 & 25 & 25 & 25 & 25 & 25 & 25 \\
\hline HPMC 4000 & 15 & 30 & 45 & & & & & & & & & \\
\hline HPMC 15000 & & & & 15 & 30 & 45 & & & & 30 & 30 & 30 \\
\hline CMC sodium & & & & & & & 15 & 30 & 45 & & & \\
\hline $\begin{array}{l}\text { Sodium } \\
\text { Bicarbonate }\end{array}$ & 4.5 & 4.5 & 4.5 & 4.5 & 4.5 & 4.5 & 4.5 & 4.5 & 4.5 & - & 10.5 & 15 \\
\hline $\begin{array}{l}\text { Anhydrous } \\
\text { Lactose }\end{array}$ & 104 & 89 & 74 & 104 & 89 & 74 & 104 & 89 & 74 & 93.5 & 83 & 78.5 \\
\hline $\begin{array}{l}\text { Magnesium } \\
\text { Stearate }\end{array}$ & 1.5 & 1.5 & 1.5 & 1.5 & 1.5 & 1.5 & 1.5 & 1.5 & 1.5 & 1.5 & 1.5 & 1.5 \\
\hline Total & 150 & 150 & 150 & 150 & 150 & 150 & 150 & 150 & 150 & 150 & 150 & 150 \\
\hline
\end{tabular}

1.2- Evaluation of the Prepared Conventional Celecoxib Floating Capsules

The prepared Celecoxib capsules were evaluated for the uniformity of weight and drug content.

\subsection{1- Uniformity of weight}

Twenty capsules were weighed individually. The contents of each capsule were removed and the empty shells were weighed individually again. The net weight of the content of each capsule was calculated by subtracting the weight of the shell from the respective gross weight. The average weight was determined according to the USP XXV.

\subsection{2- Uniformity of drug content}

Random samples of 10 capsules from each batch were tested for the uniformity of drug content. The contents of capsules were removed by opening each capsule individually and the drug in each was extracted with $100 \mathrm{ml}$ of methanol. The solution was filtered, suitably diluted with $0.1 \mathrm{~N} \mathrm{HCl}$ and assay spectrophotometrically at $\lambda$ the maximum wave length of $252 \mathrm{~nm}$ for Celecoxib content using the suitable blank. 


\subsection{3- Floating Behavior of the Prepared Conventional Celecoxib Floating Capsules}

The USP dissolution apparatus (USP apparatus II) was used in this test. The glass vessels of the apparatus were filled with $500 \mathrm{ml}$ of $0.1 \mathrm{~N}$. $\mathrm{HCl}$ (simulated gastric fluid without enzymes) maintained at $37 \pm 0.5^{\circ} \mathrm{C}$ and rotated at $100 \mathrm{rpm}$.

The buoyancy lag time and the duration of buoyancy of the prepared Celecoxib floating capsules were determined. The time taken by each formula to start floating (floating lag time) was determined. The time for each dosage form to remain buoyant (floated) over the solution was determined and taken as the floating time (Ingani et al., 1987; Yang, 1999).

\subsection{4- In-Vitro Drug Release Study from the Prepared Conventional Floating Capsules}

The release rates of Celecoxib from the prepared floating capsules were determined using USP apparatus II (paddle-type) rotated at $100 \mathrm{rpm}$. The dissolution medium consisted of $500 \mathrm{ml}(\mathrm{pH} 1.2)$ maintained at $37 \pm 0.5^{\circ} \mathrm{C}$.

One capsule from each formula (containing $25 \mathrm{mg}$ Celecoxib) was placed in each vessel and subjected to the dissolution test.

Samples $(5 \mathrm{ml}$ of aliquot) were withdrawn with volumetric pipette at predetermined time intervals of $15,30,60,90,120,150,180,240,300,360,240$ and 480 minutes and filtered off. The medium was replenished immediately with the same volume of fresh dissolution medium maintained at the same temperature. Samples were analyzed by using UV spectrophotometer for their Celecoxib content at $\lambda_{\max }=252 \mathrm{~nm}$ against the blank (Sinha $\boldsymbol{e t}$ al., 2007; Dua et al., 2007). The test was done in a triplicate manner and the mean values were considered.

\section{2- Celecoxib Mixtures}

\section{1- Preparation of Celecoxib Physical Mixtures}

Physical mixtures of Celecoxib with either Aerosil 200 or Florite ${ }^{\circledR}$ at a ratio of $(1: 1$, 1:3 and 1:5 w/w drug: adsorbent) were prepared by gentle and smooth mixing of the required amount of the drug and the adsorbent using a glass pestle and a mortar. The prepared mixtures were sieved to obtain a particle size range of $125-250 \mu \mathrm{m}$ and then stored in a desiccator over calcium chloride till investigation.

\section{2- Preparation Of Celecoxib Ground Mixtures}

Ground mixtures of Celecoxib with Florite ${ }^{\circledR}$ or Aerosil 200 at 1:1, 1:3 and 1:5 w/w drug: adsorbent ratios were prepared by grinding the physical mixtures of the drug with each adsorbent in a vibrating uniball mill for $15 \mathrm{~min}$. The prepared mixtures were sieved to obtain a particle size range of $125-250 \mu \mathrm{m}$ and then stored in a desiccator over calcium chloride till use.

\section{3- Preparation of Celecoxib Loaded Mixtures by Solvent Deposition Method}

Initially, Florite ${ }^{\circledR}$ and Aerosil 200 were activated in a vacuum drier at $110{ }^{\circ} \mathrm{C}$ and 70 ${ }^{\circ} \mathrm{C}$ for 3 and 24 hours respectively, after that the materials were kept at a room temperature in a desiccator over calcium chloride till investigation. Loaded mixtures of Celecoxib with either Florite ${ }^{\circledR}$ or Aerosil 200 were prepared by solvent deposition method of 1:1, 1:3 and 1:5 w/w drug: adsorbent ratios. Accordingly, the required amount of Celecoxib was dissolved in methanol and the required amount of the adsorbent was added with stirring for $30 \mathrm{~min}$ then the solvent was evaporated in vacuum at $40{ }^{\circ} \mathrm{C}$ till constant weight was obtained. A particle size range of $125-250 \mu \mathrm{m}$ was selected prepared and then stored in a desiccator over calcium chloride till use.

\section{4- Preparation of Celecoxib Co-adsorbates}

Celecoxib solubilized in the investigated surfactant solutions was adsorbed onto surface of Florite ${ }^{\circledR}$ or Aerosil 200 using solvent deposition method. The calculated amount of each adsorbent was added to methanolic solution of drug and surfactant to obtain the desired weight ratios of drug to surfactant to adsorbent of $(1: 1: 5,1: 3: 5$ and 1:5:5 w/w drug: 
surfactant: carrier). The solution was treated using the same procedure described under preparation of adsorbates.

\section{5- Compatibility and Characterization Study of Celecoxib Adsorbates \\ 2.5.1- Infrared Spectroscopy:}

Samples (1-2 mg) of drug alone, physical mixture, groung mixture, adsorbate and coadsorbate were mixed with potassium bromide (IR grade), compressed into discs in the compressor unit under vacuum, and scanned from $4000-800 \mathrm{~cm}^{-1}$ with an empty pellet holder as a reference.

\subsection{2- Differential Scanning Calorimetric Studies}

Samples (3-6 mg) were weighed and hermetically sealed in flat-bottomed aluminum pans. Samples of drug alone, excipients alone as well as their corresponding physical mixtures $(1 ; 1 \mathrm{w} / \mathrm{w})$ prepared by simple blending and prefect mixing on a clean waxy paper were subjected DSC investigation. The DSC thermograms were obtained over a temperature range of $30-250{ }^{\circ} \mathrm{C}$ with a thermal analyzer equipped with advanced computer software program at a scanning rate of $10^{\circ} \mathrm{C} / \mathrm{min}$ and $\mathrm{N}_{2}$ purge of $40 \mathrm{ml} / \mathrm{min}$. the instrument was calibrated with indium as a standard.

\subsection{3- Powder X-Ray Diffraction (P-XRD)}

The X-ray diffractograms for different samples with particle size range of (250-125) $\mu \mathrm{m}$ were determined using the Philips 1710 automated diffractometer. The relation was provided by Cukó radiation operating at $40 \mathrm{KV}$ and current of $30 \mathrm{~mA} \mathrm{~K} \alpha=1.5418$. The system was calibrated using standard polycrystalline silicon. The differential patterns were achieved using continuous scan mode with $2 \theta$ ranging from $4^{\circ}$ to $60^{\circ}$. The obtained output data were represented by $2 \theta$, dA intensities and determined via the microprocessor of the $\mathrm{PW} / 1710$.

\subsection{4- Determination of Drug Content of the Prepared Celecoxib Adsorbates}

An accurately weighed sample of the prepared Celecoxib adsorbates equivalent to $25 \mathrm{mg}$ of the drug was added to $100 \mathrm{ml}$ volumetric flask, then dissolved in minimum amount of alcohol and complete the volume to $100 \mathrm{ml}$ by $\mathrm{HCl}$ buffer ( $\mathrm{pH}$ 1.2). After suitable dilution, Celecoxib content was determined spectrophotometrically at $\lambda_{\max } 252 \mathrm{~nm}$. Only those samples containing $100 \pm 5 \%$ of the claimed amounts of Celecoxib were considered for further studies.

\subsection{5- In-Vitro Dissolution Studies of the Prepared Celecoxib Adsorbates}

Dissolution experiments were carried out in triplicate with USP apparatus II dissolution using paddle at a rotation speed of $100 \mathrm{rpm}$. Powdered samples of each preparation equivalent to $25 \mathrm{mg}$ of Celecoxib were added to the dissolution medium $(900 \mathrm{ml} \mathrm{of} \mathrm{pH} \mathrm{1.2}) \mathrm{kept}$ at $37 \pm 0.5^{\circ} \mathrm{C}$. At appropriate time intervals, $5 \mathrm{ml}$ of the solution was withdrawn using cotton plug from the dissolution medium and replaced with an equal volume of the fresh dissolution medium equilibrated at $37^{\circ} \mathrm{C}$. The samples were assayed spectrophotometrically at $\lambda_{\max } 252$ $\mathrm{nm}$. It was found that none of the additives used interfered with the spectrophotometric assay of the drug in the dilution range used. The mean of three determinations was considered.

\section{3 - Celecoxib Adsorbates Floating Capsules}

\section{1 - Preparation of Celecoxib Adsorbates Floating Capsules}

Celecoxib powder or its coadsorbate with polysorbate 80 onto Florite $\AA$, mixed with different concentrations of HPMC $4000(12.5,25$, and $50 \mathrm{mg})$ were used for the preparation of floating capsule dosage forms. Sodium bicarbonate was used in a concentration of $10.5 \mathrm{mg}$ $\mathrm{w} / \mathrm{w}$ of capsule, while magnesium stearate was added in a concentration of $1 \% \mathrm{w} / \mathrm{w}$ of capsule. Anhydrous lactose was used a filler to obtain the desired weight of capsules. Floating capsule dosage forms were prepared by manual filling. The different formulae of floating capsule dosage forms of Celecoxib show the amount of each ingredient in mg. The prepared formulae of floating capsule dosage forms are given the symbols of C1-C6, see table (2). 
Table (2): Formulation of Floating Capsules Containing Celecoxib Co-adsorbate

\begin{tabular}{|c|c|c|c|c|c|c|c|c|}
\hline \multirow{2}{*}{$\begin{array}{l}\text { Formula } \\
\text { No. }\end{array}$} & \multicolumn{3}{|c|}{ Co-adsorbate } & \multirow{2}{*}{$\begin{array}{l}\text { HPMC } \\
4000 \\
(\mathbf{m g})\end{array}$} & \multirow{2}{*}{$\begin{array}{l}\text { Sodium } \\
\text { Bicarbonate } \\
\text { (mg) }\end{array}$} & \multirow{2}{*}{$\begin{array}{l}\text { Magnesium } \\
\text { Stearate } \\
(\mathrm{mg})\end{array}$} & \multirow{2}{*}{$\begin{array}{l}\text { Anhydrous } \\
\text { Lactose } \\
\text { (mg) }\end{array}$} & \multirow{2}{*}{$\begin{array}{l}\text { Total } \\
(\mathbf{m g})\end{array}$} \\
\hline & $\begin{array}{l}\text { Celecoxib } \\
(\mathrm{mg})\end{array}$ & $\begin{array}{l}\text { Florite } \\
\text { R } \\
\text { ( mg ) }\end{array}$ & $\begin{array}{l}\text { Polysorbate } \\
80(\mathrm{mg})\end{array}$ & & & & & \\
\hline $\mathrm{C}_{1}$ & 25 & 25 & 25 & 25 & 10.5 & 3.5 & 236 & 350 \\
\hline $\mathrm{C}_{2}$ & 25 & 50 & 75 & 25 & 10.5 & 3.5 & 161 & 350 \\
\hline $\mathrm{C}_{3}$ & 25 & 75 & 125 & 25 & 10.5 & 3.5 & 86 & 350 \\
\hline $\mathrm{C}_{4}$ & 25 & 125 & 75 & 25 & 10.5 & 3.5 & 86 & 350 \\
\hline $\mathrm{C}_{5}$ & 25 & 125 & 75 & 50 & 10.5 & 3.5 & 61 & 350 \\
\hline C6 & 25 & 125 & 75 & 12.5 & 10.5 & 3.5 & 98.5 & 350 \\
\hline
\end{tabular}

The calculated amounts of each ingredient were mixed in a large dish till a homogenous mixture was obtained. The powder blend was then placed on a horizontal plate. Hard gelatin capsules No. 000 were filled manually by bunching the capsule body against the powder sheet.

The weight of each filled capsule was adjusted to the required weight $(350 \mathrm{mg})$. Different formulae of floating capsule dosage forms of Celecoxib show the amount of each ingredient in $\mathrm{mg}$. The prepared formulae of floating capsule dosage forms are given the symbols of C1-C6.

\section{2- Evaluation and Charaterization of Celecoxib Adsorbates Capsules}

\subsection{1- Floating Time of the Prepared Celecoxib Adsorbates Capsules}

The prepared floating capsules of Celecoxib adsorbates were evaluated as previously described.

\subsection{2- In-Vitro Drug Release Study of Celecoxib from Adsorbates Floating Capsules}

The USP dissolution apparatus (USP apparatus II) was used in this test. The glass vessels of the apparatus were filled with $500 \mathrm{ml}$ of $0.1 \mathrm{NHCl}$ buffer $\mathrm{pH} 1.2$ (simulated gastric fluid without enzymes) and all maintained at $37 \pm 0.5^{\circ} \mathrm{C}$ and rotated at $100 \mathrm{rpm}$. The release rates of Celecoxib from the prepared floating capsules and tablets were determined using USP rotating paddle method (USP apparatus II). One capsule or tablet from each formula (containig $25 \mathrm{mg}$ of Celecoxib) was placed in each vessel and subjected to the dissolution test.

Each dissolution test was composed of three test samples and a blank solution that was running hand in hand with the test experiments. At specified time intervals, $5 \mathrm{ml}$ samples were withdrawn from the dissolution media and filtered off. The UV absorbance of the drug was measured at $\lambda_{\max }=252 \mathrm{~nm}$ against the obtained blank. The dissolution volume was kept constant over the dissolution time. Therefore, at each time interval and after sample withdrawal, the volume was completed immediately using the dissolution medium preheated to $37^{\circ} \mathrm{C}$. The release results were cumulatively corrected for the withdrawn samples.

The mean and standard deviation (of three results) were calculated for each time point and the final results were subjected to kinetic evaluation.

\section{RESULTS AND DISCUSSION}

\section{Conventional Celecoxib Floating Capsules}

\section{1- Evaluation of the Prepared Conventional Celecoxib Floating Capsules}

Table (3) showed the mean weight and the mean drug content of the prepared Celecoxib capsules. The results showed that all the prepared capsules are uniform in weight according to USP XXV limits. The percent of the total drug content of the prepared capsules 
was in the range of $99.75 \pm 0.05$ to $100.7 \pm 0.14$. These values indicate that all the prepared capsules are in accordance with USP XXV requirements (USP XXV, 25 ${ }^{\text {th }}$ ed., 2002)..

Table (3): Weight Variation and Drug Content of the Prepared Celecoxib Floating Capsules

\begin{tabular}{|l|l|l|}
\hline Formula No. & Weight Variation $( \pm$ SD) & Drug content $(\% \pm$ SD) \\
\hline FC1 & $150.2( \pm 0.01)$ & $99.87( \pm 0.18)$ \\
\hline FC2 & $150.5( \pm 0.08)$ & $100.7( \pm 0.14)$ \\
\hline FC3 & $150.7( \pm 0.01)$ & $100.1( \pm 0.21)$ \\
\hline FC4 & $150.5( \pm 0.01)$ & $100.3( \pm 0.24)$ \\
\hline FC5 & $150.3( \pm 0.01)$ & $1002 .( \pm 0.31)$ \\
\hline FC6 & $150.5( \pm 0.09)$ & $100.2( \pm 0.16)$ \\
\hline FC7 & $150.7( \pm 0.07)$ & $100.2( \pm 0.13)$ \\
\hline FC8 & $150.3( \pm 0.01)$ & $99.75( \pm 0.05)$ \\
\hline FC9 & $150.4( \pm 0.01)$ & $100.4( \pm 0.16)$ \\
\hline FC10 & $150.3( \pm 0.01)$ & $99.91( \pm 0.22)$ \\
\hline FC11 & $150.4( \pm 0.05)$ & $100.1( \pm 0.31)$ \\
\hline FC12 & $150.6( \pm 0.06)$ & $100.3( \pm 0.43)$ \\
\hline
\end{tabular}

1.2-Floating behavior of Conventional Celecoxib floating capsules

Table (4) showed the floating times and behaviors of the different prepared Celecoxib floating capsules $\left(\mathrm{FC}_{1}-\mathrm{FC}_{12}\right)$ in dissolution medium of $\mathrm{pH}$ 1.2. The floating time is taken as the period of time during which the capsule remains floating on the gastric fluid. After the hard gelatin capsule shell dissolved, the capsule contents adhered together forming a single unit that continued to float and swell gradually. During this time, Celecoxib diffused through the coadhered matrix to be released into the dissolution medium. All the prepared formulae of Celecoxib capsules floated immediately upon contact with the release medium, showing no lag times in floating behavior because the low density is provided from the beginning of the experiment $(\mathrm{t}=0 \mathrm{~min})$.

Celecoxib floating capsules (formulae $\mathrm{FC}_{1}-\mathrm{FC}_{3}$ ) containing different concentrations of HPMC 4000 and 3\% sodium bicarbonate using anhydrous lactose as a filler did not maintain their physical integrity for the desired period ( 8 hours) of time (Table 4 ). Hence, an attempt was carried out in order to increase the physical integrity of the capsules using HPMC 15000 .

Extended floating time ( 8 hours) is achieved for Celecoxib floating capsules (formulae $\mathrm{FC}_{4}-\mathrm{FC}_{6}$ ) because the contents of capsules did not rapture but retained their definite shapes while floating. This may be due to the air entrapped within the HPMC 15000 matrix, which is only slowly removed from the system upon contact with the release medium.

Table (4) illustrates the effect of increasing the concentration of sodium bicarbonate $(0 \%, 7 \%$, and $10 \% \mathrm{w} / \mathrm{w})$ on the floating times and behaviors of Celecoxib floating capsule containing 20\% w/w of mg HPMC 15000 and anhydrous lactose as a filler. Celecoxib floating capsule (Formula $\mathrm{FC}_{10}$ without sodium bicarbonate) did not maintain its physical integrity over one hour and the content of the capsule dispersed into smaller floating fragments. This may be attributed to the absence of the gas generating agent which acts to keep the dosage form buoyant on the dissolution medium. While formulae $\mathrm{FC}_{11}$ and $\mathrm{FC}_{12}$ (containing $7 \%$ and $10 \% \mathrm{w} / \mathrm{w}$ sodium bicarbonate, respectively) gave excellent floating behavior and were capable of maintaining their physical integrity throughout the whole dissolution test ( 8 hours). They swelled gradually and remained buoyant on the surface of the dissolution medium. In such systems, sodium bicarbonate reacts with the gastric hydrochloric acid to give carbon dioxide retained bubbles which cause floating of the capsule on the surface of the gastric content. 
The effect of different concentration of $\operatorname{NaCMC}(10,20,30 \% \mathrm{w} / \mathrm{w})$ in formulae $\left(\mathrm{Fc}_{7^{-}}\right.$ $\mathrm{Fc}_{9}$ ) respectively on the floating time and behaviors is shown in table (4). It was found that the solution slightly turbid because of the swelled matrix did not maintain integrity over 1.5 hr.

Table (4): Floating Behaviors of the Prepared Celecoxib Floating Capsules (Formulae $\mathrm{FC}_{1^{-}}$ $\left.\mathrm{FC}_{12}\right)$.

\begin{tabular}{|c|c|c|c|}
\hline $\begin{array}{l}\text { Formula } \\
\text { no. }\end{array}$ & $\begin{array}{l}\text { Lag time } \\
\text { of } \\
\text { floating }\end{array}$ & Floating time & Description \\
\hline $\begin{array}{ll}\mathbf{F C}_{1} & \& \\
\mathbf{F C}_{2} & \end{array}$ & Immediate & 1.5 hour & $\begin{array}{l}\text { The solution was slightly turbid because of } \\
\text { the swelled matrix did not maintain } \\
\text { integrity over } 1.5 \text { hour the fragments of the } \\
\text { hydrogel remained on the surface of the } \\
\text { dissolution test medium until the hydrogel } \\
\text { dissolved completely. }\end{array}$ \\
\hline $\mathbf{F C}_{3}$ & Immediate & 1.75 hour & $\begin{array}{l}\text { The solution slightly turbid because of the } \\
\text { swelled matrix did not maintain integrity } \\
\text { over } 1.75 \text { hour the fragments of the } \\
\text { hydrogel remained on the surface of the } \\
\text { dissolution test medium until the hydrogel } \\
\text { dissolved completely. }\end{array}$ \\
\hline $\mathrm{FC}_{4}-\mathrm{FC}_{6}$ & Immediate & $\begin{array}{l}\text { All the dissolution } \\
\text { period ( } 8 \text { hours) }\end{array}$ & $\begin{array}{l}\text { The solution was clear because of the } \\
\text { content of capsule did not rupture where is } \\
\text { the absorption of water caused the capsule } \\
\text { increase in the size and take the shape of } \\
\text { gelatinous mass structure }\end{array}$ \\
\hline $\mathrm{FC}_{7}-\mathrm{FC}_{9}$ & Immediate & 1.5 hour & $\begin{array}{l}\text { The solution was slightly turbid because of } \\
\text { the swelled matrix did not maintain } \\
\text { integrity over } 1.5 \text { hour }\end{array}$ \\
\hline $\mathbf{F C}_{10}$ & Immediate & 1 hours & $\begin{array}{l}\text { Over the floating time stated the swelled } \\
\text { matrix did not maintain its integrity. } \\
\text { Furthermore, the content of the capsule } \\
\text { dispersed however, some fragments of the } \\
\text { hydrogel remained floating. }\end{array}$ \\
\hline $\begin{array}{l}\mathrm{FC}_{11} \& \mathrm{FC} \\
12\end{array}$ & Immediate & $\begin{array}{l}\text { All the dissolution } \\
\text { period ( } 8 \text { hours) }\end{array}$ & $\begin{array}{l}\text { During floating time it was observed that } \\
\text { the content of the capsule did not rapture } \\
\text { but still retained its shape. Also, the } \\
\text { increase in the size of the capsule possibly } \\
\text { attributed to the absorption of water } \\
\text { causing the formation of gelatinous mass } \\
\text { structure. }\end{array}$ \\
\hline
\end{tabular}

\section{3-In-Vitro Drug Release Study from the Prepared Conventional Floating Capsules}

Table (5) and Figure (1 A) showed the effect of different concentrations of HPMC 4000 on the release of Celecoxib from floating capsules $\left(\mathrm{FC}_{1}-\mathrm{FC}_{3}\right)$ containing anhydrous lactose as a filler and $3 \% \mathrm{w} / \mathrm{w}$ sodium bicarbonate as gas-generating agent at $\mathrm{pH} 1.2$. It was found that by increasing the concentration of HPMC 4000 (from 10-30 w/w), decreased in the release rate of the drug from 42.25 to $37.28 \%$ after $480 \mathrm{~min}$. 
Table (5) and Figure (1 B) show the effect of different concentrations of HPMC 15000 on the release of Celecoxib from floating capsules $\left(\mathrm{FC}_{4}-\mathrm{FC}_{6}\right)$ containing anhydrous lactose as a filler and $3 \% \mathrm{w} / \mathrm{w}$ sodium bicarbonate at $\mathrm{pH} 1.2$. Celecoxib floating capsule containing different concentration of HPMC 15000 gave slowest release rate of the drug among the investigated floating capsules after the same time. Furthermore, increasing the amounts added of HPMC 15000 led to lower percentage of Celecoxib released from the floating capsules. Cumulative drug released from formulae $\mathrm{FC}_{4}, \mathrm{FC}_{5}$, and $\mathrm{FC}_{6}$ after 480 min was found to be $31.24 \%, 28.82 \%$ and $25.01 \%$ respectively.

Generally it was found that the release of Celecoxib from HPMC 4000 treated formulations was higher compared with those obtained from HPMC 15000 treated formulations. This can probably be attributed to the different diffusion and swelling behavior in/of these polymers. With increasing the molecular weight, the degree of entanglement of the polymer chain increases. Thus, the mobility of the macromolecules in the fluffy swollen systems decreases. According to the free volume theory of diffusion, the probability for a diffusing molecule to jump from one cavity into another, hence, decreases (Fan and Singh 1989). This leads to decreased drug diffusion coefficients and decreased drug release rates with increasing the molecular weights.

Table (5) and Figure (1 C) showed the effect of different concentration of sodium $\mathrm{CMC}$ as a swelling matrix on the release of Celecoxib from floating capsules $\left(\mathrm{FC}_{7}-\mathrm{FC}_{9}\right)$ containing anhydrous lactose as a filler and $3 \% \mathrm{w} / \mathrm{w}$ sodium bicarbonate at $\mathrm{pH} 1.2$. Similar release rates of the drug were obtained form Celecoxib floating capsules containing different concentration rate of $\mathrm{NaCMC}\left(\mathrm{Fc}_{7}-\mathrm{Fc}_{9}\right)$ with capsules containing $\mathrm{HPMC} 4000\left(\mathrm{FC}_{1}-\mathrm{FC}_{3}\right)$ using the same filler and gas generating agent.

The effect of different concentrations $(0,7,10 \% \mathrm{w} / \mathrm{w})$ of sodium bicarbonate $\left(\mathrm{FC}_{10}-\right.$ $\mathrm{FC}_{12}$ ) on dissolution profile of Celecoxib from floating capsules was presented in Figure (1 D) and Table (4). The absence and/or altering the sodium bicarbonate concentrations did not affect the percentage of Celecoxib released from formulations $\left(\mathrm{FC}_{10}-\mathrm{FC}_{12}\right)$. Where that $\mathrm{FC}_{10}, \mathrm{FC}_{11}$ and $\mathrm{FC} 12$ showed $28.05 \%, 27.91 \%$ and $28.88 \%$ released of Celecoxib from floating capsules formulations, respectively, this might be attributed to the high viscosity of HPMC 15000 as described above.

Table (5) Percentage of drug Release from the Conventional Floating Capsules at pH1.2

\begin{tabular}{|c|c|c|c|c|c|c|c|c|c|c|c|c|}
\hline \multirow{2}{*}{$\begin{array}{l}\text { Formula No. } \\
\text { Time (min) }\end{array}$} & \multicolumn{12}{|c|}{ Percentage released of Celecoxib } \\
\hline & $\mathbf{F C}_{1}$ & $\mathbf{F C}_{2}$ & $\mathbf{F C}_{3}$ & $\mathbf{F C}_{4}$ & $\mathbf{F C}_{5}$ & $\mathbf{F C}_{6}$ & $\mathbf{F C}_{7}$ & $\mathbf{F C}_{8}$ & $\mathbf{F C}_{9}$ & $\mathrm{FC}_{10}$ & $\mathrm{FC}_{11}$ & $\mathbf{F C}_{12}$ \\
\hline 15 & $\begin{array}{l}12.06 \\
\pm 0.66\end{array}$ & $\begin{array}{l}11.81 \\
\pm 0.93\end{array}$ & $\begin{array}{l}10.42 \\
\pm 0.51\end{array}$ & $\begin{array}{l}5.09 \\
\pm 0.45\end{array}$ & $\begin{array}{l}4.89 \\
\pm 0.30\end{array}$ & $\begin{array}{l}3.21 \\
\pm 0.29\end{array}$ & $\begin{array}{l}11.92 \\
\pm 0.84\end{array}$ & $\begin{array}{l}10.21 \\
\pm 0.57\end{array}$ & $\begin{array}{l}9.98 \\
\pm 0.75\end{array}$ & $\begin{array}{l}5.02 \\
\pm 0.23\end{array}$ & $\begin{array}{l}4.92 \\
\pm 0.30\end{array}$ & $\begin{array}{l}4.12 \\
\pm 0.29\end{array}$ \\
\hline 30 & $\begin{array}{l}13.21 \\
\pm 0.69\end{array}$ & $\begin{array}{l}12.04 \\
\pm 1.02 \\
\end{array}$ & $\begin{array}{r}11.39 \\
\pm 0.57 \\
\end{array}$ & $\begin{array}{l}7.92 \\
\pm 0.39\end{array}$ & $\begin{array}{l}5.39 \\
\pm 0.41\end{array}$ & $\begin{array}{l}3.95 \\
\pm 0.57\end{array}$ & $\begin{array}{r}12.05 \\
\pm 0.30\end{array}$ & $\begin{array}{r}12.01 \\
\pm 0.45\end{array}$ & $\begin{array}{r}10.49 \\
\pm 0.57\end{array}$ & $\begin{array}{l}5.99 \\
\pm 0.29 \\
\end{array}$ & $\begin{array}{ll}5.02 \\
\pm 0.35\end{array}$ & $\begin{array}{l}6.22 \\
\pm 0.25 \\
\end{array}$ \\
\hline 60 & $\begin{array}{l}15.85 \\
\pm 0.58\end{array}$ & $\begin{array}{l}13.71 \\
\pm 1.08\end{array}$ & $\begin{array}{l}12.05 \\
\pm 0.63\end{array}$ & $\begin{array}{l}9.53 \\
\pm 0.40\end{array}$ & $\begin{array}{l}7.19 \\
\pm 0.32\end{array}$ & $\begin{array}{l}5.04 \\
\pm 0.63\end{array}$ & $\begin{array}{l}13.92 \\
\pm 0.51\end{array}$ & $\begin{array}{l}14.21 \\
\pm 0.36\end{array}$ & $\begin{array}{r}12.29 \\
\pm 0.60\end{array}$ & $\begin{array}{l}7.22 \\
\pm 0.28\end{array}$ & $\begin{array}{l}6.92 \\
\pm 0.39\end{array}$ & \begin{tabular}{|l|}
8.29 \\
\pm 0.36
\end{tabular} \\
\hline 90 & $\begin{array}{r}18.22 \\
\pm 0.72\end{array}$ & $\begin{array}{r}16.83 \\
\pm 0.75\end{array}$ & $\begin{array}{r}14.35 \\
\pm 0.93 \\
\end{array}$ & $\begin{array}{l}12.22 \\
\pm 0.38\end{array}$ & $\begin{array}{r}11.22 \\
\pm 0.39\end{array}$ & $\begin{array}{l}8.92 \\
\pm 0.61\end{array}$ & $\begin{array}{r}15.23 \\
\pm 0.78 \\
\end{array}$ & $\begin{array}{r}15.98 \\
\pm 0.69\end{array}$ & $\begin{array}{r}15.32 \\
\pm 0.73\end{array}$ & $\begin{array}{r}10.29 \\
\pm 0.35\end{array}$ & $\begin{array}{l}9.88 \\
\pm 0.29\end{array}$ & $\begin{array}{l}11.01 \\
\pm 0.42 \\
\end{array}$ \\
\hline 120 & $\begin{array}{l}20.26 \\
\pm 1.05\end{array}$ & $\begin{array}{r}17.92 \\
\pm 0.63\end{array}$ & $\begin{array}{r}15.06 \\
\pm 1.08 \\
\end{array}$ & $\begin{array}{l}13.16 \\
\pm 0.50\end{array}$ & $\begin{array}{r}12.05 \\
\pm 0.39\end{array}$ & $\begin{array}{r}10.03 \\
\pm 0.63\end{array}$ & $\begin{array}{r}18.26 \\
\pm 0.58\end{array}$ & $\begin{array}{r}18.01 \\
\pm 0.75\end{array}$ & $\begin{array}{r}17.07 \\
\pm 0.45\end{array}$ & $\begin{array}{l}12.26 \\
\pm 0.36\end{array}$ & $\begin{array}{l}11.52 \\
\pm 0.42 \\
\end{array}$ & $\begin{array}{r}12.98 \\
\pm 0.38 \\
\end{array}$ \\
\hline 150 & $\begin{array}{l}24.92 \\
\pm 0.4\end{array}$ & $\begin{array}{l}21.9 \\
\pm 0.87\end{array}$ & \begin{tabular}{|l|}
18.21 \\
\pm 1.17 \\
\end{tabular} & $\begin{array}{r}14.85 \\
\pm 0.61\end{array}$ & $\begin{array}{r}13.63 \\
\pm 0.42\end{array}$ & $\begin{array}{r}12.62 \\
\pm 0.42\end{array}$ & $\begin{array}{l}20.01 \\
\pm 0.93 \\
\end{array}$ & $\begin{array}{r}20.22 \\
\pm 0.60\end{array}$ & $\begin{array}{r}19.20 \\
\pm 0.45 \\
\end{array}$ & $\begin{array}{r}12.98 \\
\pm 0.40 \\
\end{array}$ & $\begin{array}{l}13.02 \\
\pm 0.46 \\
\end{array}$ & $\begin{array}{r}14.59 \\
\pm 0.25 \\
\end{array}$ \\
\hline 180 & $\begin{array}{r}29.23 \\
\pm 0.84\end{array}$ & $\begin{array}{r}24.05 \\
\pm 0.57\end{array}$ & $\begin{array}{l}20.33 \\
\pm 0.75\end{array}$ & $\begin{array}{l}17.92 \\
\pm 0.59\end{array}$ & $\begin{array}{l}15.01 \\
\pm 0.47\end{array}$ & $\begin{array}{l}13.23 \\
\pm 0.51\end{array}$ & $\begin{array}{l}23.92 \\
\pm 0.66\end{array}$ & $\begin{array}{l}23.91 \\
\pm 0.93\end{array}$ & $\begin{array}{r}21.05 \\
\pm 0.51\end{array}$ & $\begin{array}{l}14.52 \\
\pm 0.38\end{array}$ & $\begin{array}{l}15.09 \\
\pm 0.45\end{array}$ & $\begin{array}{l}17.33 \\
\pm 0.37\end{array}$ \\
\hline 240 & $\begin{array}{l}31.22 \\
\pm 0.30\end{array}$ & $\begin{array}{r}28.72 \\
\pm 0.45\end{array}$ & $\begin{array}{r}26.07 \\
\pm 0.57 \\
\end{array}$ & $\begin{array}{r}19.32 \\
\pm 0.30\end{array}$ & $\begin{array}{l}17.02 \\
\pm 0.35\end{array}$ & $\begin{array}{r}14.98 \\
\pm 0.57\end{array}$ & $\begin{array}{r}29.23 \\
\pm 0.69 \\
\end{array}$ & $\begin{array}{l}27.21 \\
\pm 1.02 \\
\end{array}$ & $\begin{array}{l}25.92 \\
\pm 0.57\end{array}$ & \begin{tabular}{|l}
17.29 \\
\pm 0.30
\end{tabular} & $\begin{array}{l}16.98 \\
\pm 0.35\end{array}$ & $\begin{array}{r}19.29 \\
\pm 0.45 \\
\end{array}$ \\
\hline 300 & 34.61 & 31.09 & 29.22 & 21.26 & 20.01 & 16.29 & 32.91 & 30.33 & 28.95 & 19.39 & 18.53 & 21.38 \\
\hline
\end{tabular}




\begin{tabular}{|c|c|c|c|c|c|c|c|c|c|c|c|c|}
\hline & \pm 0.51 & \pm 0.36 & \pm 0.60 & \pm 0.51 & \pm 0.45 & \pm 0.60 & \pm 0.58 & \pm 1.08 & \pm 0.63 & \pm 0.42 & \pm 0.27 & \pm 0.36 \\
\hline 360 & $\begin{array}{r}36.05 \\
\pm 0.78\end{array}$ & $\begin{array}{l}33.31 \\
\pm 0.69\end{array}$ & $\begin{array}{l}31.52 \\
\pm 0.73\end{array}$ & $\begin{array}{r}23.39 \\
\pm 0.49\end{array}$ & $\begin{array}{l}21.21 \\
\pm 0.36\end{array}$ & $\begin{array}{l}18.33 \\
\pm 0.35\end{array}$ & $\begin{array}{r}36.39 \\
\pm 0.57\end{array}$ & $\begin{array}{r}34.03 \\
\pm 0.75\end{array}$ & $\begin{array}{l}30.91 \\
\pm 0.93\end{array}$ & \begin{tabular}{|l}
20.98 \\
\pm 0.46
\end{tabular} & $\begin{array}{l}21.24 \\
\pm 0.36\end{array}$ & $\begin{array}{r}23.26 \\
\pm 0.28 \\
\end{array}$ \\
\hline 420 & $\begin{array}{l}38.52 \\
\pm 0.58 \\
\end{array}$ & $\begin{array}{l}35.6 \\
\pm 0.75 \\
\end{array}$ & $\begin{array}{r}\mathbf{3 4 . 0 7} \\
\mathbf{\pm 0 . 4 5} \\
\end{array}$ & $\begin{array}{r}27.05 \\
\pm 0.58 \\
\end{array}$ & $\begin{array}{r}24.29 \\
\pm 0.29 \\
\end{array}$ & $\begin{array}{r}20.92 \\
\pm 0.45 \\
\end{array}$ & $\begin{array}{r}39.02 \\
\pm 0.72 \\
\end{array}$ & \begin{tabular}{|l|}
36.11 \\
\pm 0.63 \\
\end{tabular} & \begin{tabular}{|l|}
33.39 \\
\pm 1.08 \\
\end{tabular} & \begin{tabular}{|l|}
25.01 \\
\pm 0.38 \\
\end{tabular} & $\begin{array}{r}25.23 \\
\pm 0.38 \\
\end{array}$ & \begin{tabular}{|l|}
26.9 \\
\pm 0.37 \\
\end{tabular} \\
\hline 480 & $\begin{array}{r}42.25 \\
\pm 0.93 \\
\end{array}$ & $\begin{array}{r}39.98 \\
\pm 0.60 \\
\end{array}$ & $\begin{array}{r}37.28 \\
\pm 0.45 \\
\end{array}$ & $\begin{array}{r}31.24 \\
\pm 0.41 \\
\end{array}$ & $\begin{array}{l}29.82 \\
\pm 0.52 \\
\end{array}$ & $\begin{array}{l}25.01 \\
\pm 0.45 \\
\end{array}$ & $\begin{array}{r}41.21 \\
\pm 1.05 \\
\end{array}$ & $\begin{array}{l}39.02 \\
\pm 0.87 \\
\end{array}$ & $\begin{array}{l}38.01 \\
\pm 1.17 \\
\end{array}$ & $\begin{array}{l}28.05 \\
\pm 0.29 \\
\end{array}$ & $\begin{array}{r}27.91 \\
\pm 0.40 \\
\end{array}$ & $\begin{array}{r}28.88 \\
\pm 0.45 \\
\end{array}$ \\
\hline
\end{tabular}

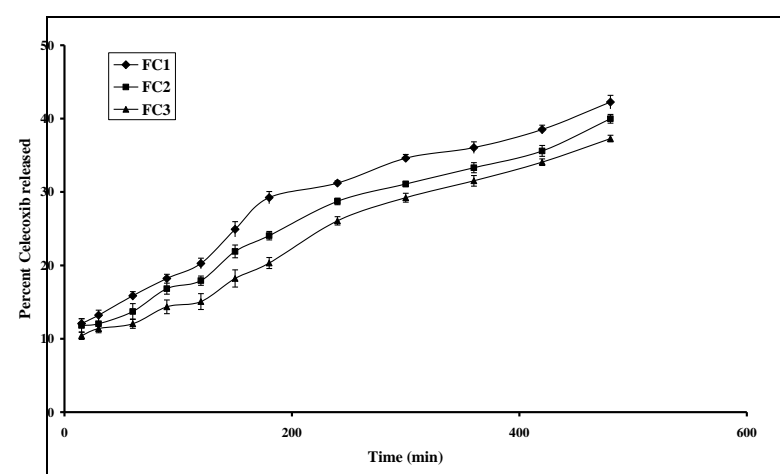

Figure (1 A): In-vitro release of Celecoxib floating capsules (FC1-FC3)

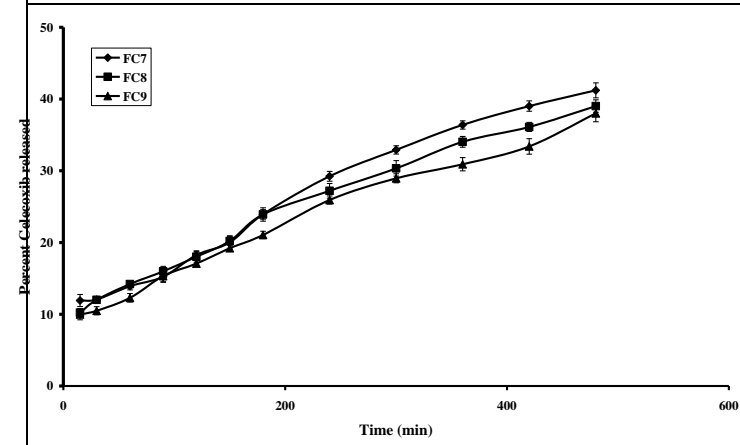

Figure (1 C): In-vitro release of Celecoxib floating capsules (FC7-FC9)

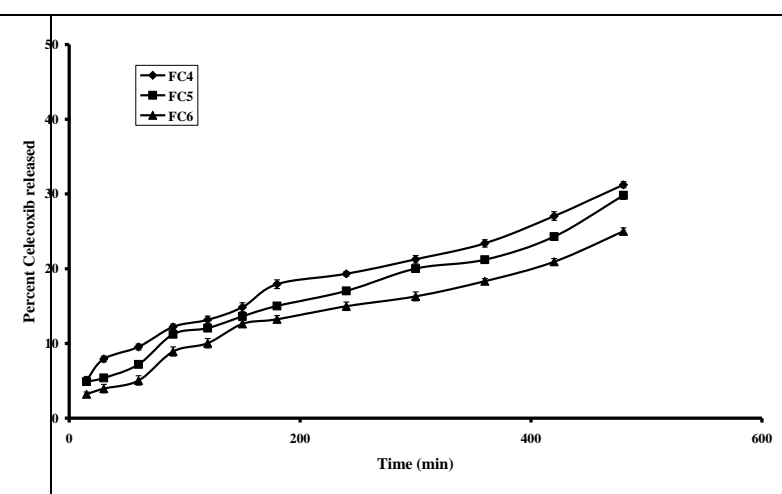

Figure (1 B): In-vitro release of Celecoxib floating capsules (FC4-FC6)

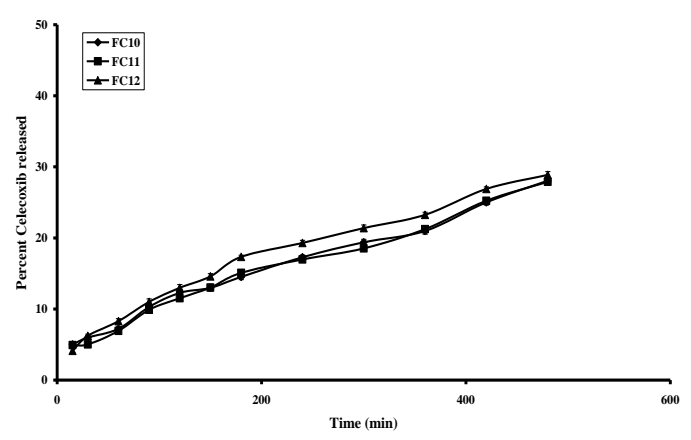

Figure (1 D): In-vitro release of Celecoxib floating capsules (FC10FC12)

\section{4- Investigation of Celecoxib release kinetics from the prepared capsules}

In order to explore the mechanism of drug release from such systems, the experimental data of Celecoxib release were subjected to kinetic treatment. Different kinetic models were applied to interpret the release rate of the drug from the prepared floating capsules. The data were treated by linear regression analysis according to zero, first-order kinetics, and simplified Higuchi diffusion model .The obtained date for these formulae of Celecoxib floating capsules were in agreement with the work done by Ingani et al., (1987) \& Gerogiannis et al., (1993).

Table (6) showed a comparison between the calculated correlation coefficient for the in-vitro release of Celecoxib floating capsules. According to the obtained results, drug release from the capsules can be described by different kinetic models (zero, first or Higuchi diffusion model) through the highest calculated correlation coefficient. 
Table (6): The Calculated Correlation Coefficients of the In-Vitro Release of Celecoxib Floating Capsules at pH 1.2 Employing Different Kinetic Orders or Systems

\begin{tabular}{|l|l|l|l|}
\hline \multirow{2}{*}{ Formula No. } & \multicolumn{3}{|c|}{ Correlation Coefficients (r ) } \\
\cline { 2 - 4 } & Zero-order & First-order & $\begin{array}{l}\text { Higuchi's diffusion } \\
\text { model }\end{array}$ \\
\hline CF1 & 0.977887 & 0.986070 & $\mathbf{0 . 9 9 0 9 9 4}$ \\
\hline CF2 & 0.990252 & $\mathbf{0 . 9 9 4 3 4 0}$ & 0.988738 \\
\hline CF3 & 0.993415 & $\mathbf{0 . 9 9 5 2 2 0}$ & 0.979349 \\
\hline CF4 & 0.988922 & $\mathbf{0 . 9 9 1 1 0 0}$ & 0.9895 \\
\hline CF5 & 0.988164 & $\mathbf{0 . 9 8 8 6 5 0}$ & 0.9845 \\
\hline CF6 & 0.981858 & 0.985050 & $\mathbf{0 . 9 8 7 8 6}$ \\
\hline CF7 & 0.992317 & $\mathbf{0 . 9 9 5 1 9 0}$ & 0.981758 \\
\hline CF8 & 0.993539 & $\mathbf{0 . 9 9 7 3 9 0}$ & 0.992128 \\
\hline CF9 & 0.994577 & $\mathbf{0 . 9 9 7 0 1 0}$ & 0.989533 \\
\hline CF10 & 0.993681 & $\mathbf{0 . 9 9 5 1 1 0}$ & 0.988941 \\
\hline CF11 & 0.992727 & $\mathbf{0 . 9 9 4 4 5 0}$ & 0.988533 \\
\hline CF12 & 0.985571 & 0.991120 & $\mathbf{0 . 9 9 7 3 8 4}$ \\
\hline
\end{tabular}

\section{2- Celecoxib Adsorbates and Co-adsorbate}

Adsorbates and co-adsorbates of Celecoxib were formulated using HPMC 4000, as it gave the higher drug release from the floating capsules among the tested cellulosic polymers. Formulation of adsorbates and co-adsorbates was aimed to increase the release of drug from the floating dosage form beside prolongation of the floating time of the capsules in gastric medium.

\section{1- Compatibility Study of Celecoxib with Adsorbates ingredients \\ 2.1.1- Infrared Spectroscopy}

In an attempt to elucidate the possible physical interactions of the different prepared systems, infrared absorption spectra were carried out. Figure (2) showed the IR spectra of pure Celecoxib, Florite ${ }^{\circledR}$ alone, its physical mixture, ground mixture and adsorbate as well as co-adsorbate systems. Curve A shows the IR spectrum of Celecoxib alone. Celecoxib has the following IR absorption bands at $3340,3233 \mathrm{~cm}^{-1}$ for the $\mathrm{NH}_{2^{-}}$group, $1103 \mathrm{~cm}^{-1}$ due to $\mathrm{SO}_{2}$ bending, $1560 \mathrm{~cm}^{-1}$ corresponding to $\mathrm{SO}_{2}$ stretching vibration and at $1347 \mathrm{~cm}^{-1}$ is assigned to $\mathrm{CH}_{3}$ bending and at $3099 \mathrm{Cm}^{-1}$ stretching vibration.

The IR spectrum of Florite ${ }^{\circledR}$ alone is characterized by absence of any characteristic infrared absorption bands due to its inorganic nature (Trace B, Figure 2). The IR spectra of Celecoxib/ Florite ${ }^{\circledR}$ physical, ground and adsorbate mixtures (Traces C, D, E, Figure 2) show all the characteristic IR bands of Celecoxib but they are reduced in their intensities due to the higher ratio of Florite ${ }^{\circledR}$ in these prepared systems. The amino group $\left(-\mathrm{NH}_{2}\right)$, of the drug in their physical, ground and adsorbate mixtures with Florite ${ }^{\circledR}$ was shifted from $3450 \mathrm{~cm}^{-1}$ to $3420 \mathrm{~cm}^{-1}, 3410 \mathrm{~cm}^{-1}$ and $3415 \mathrm{~cm}^{-1}$;respectively. This can be attributed to the interaction of Celecoxib with Florite ${ }^{\circ}$.

The IR absorption spectrum of co-adsorbates of Celecoxib with polysorbate 80 onto the surface of Florite ${ }^{\circledR}$ in a ratio of $(1: 3: 5 \mathrm{w} / \mathrm{w})$ is presented in (Figure 2, Trace F). It is clear that the major characteristic bands of the drug in its co-adsorbate are still present but with minor change and reduced in their intensities compared to plain drug. The amino group ($\mathrm{NH}_{2}$ ) of the drug in its coadsorbate was broad and shifted from $3450 \mathrm{~cm}^{-1}$ to $3405 \mathrm{~cm}^{-1}$, this may be attributed to the interaction of the drug with Florite ${ }^{\circledR}$.

It can be postulated that these molecular interactions involve weak bonds formation, e.g., hydrogen bonding or Vander Waal forces may be contributed in this interaction. 


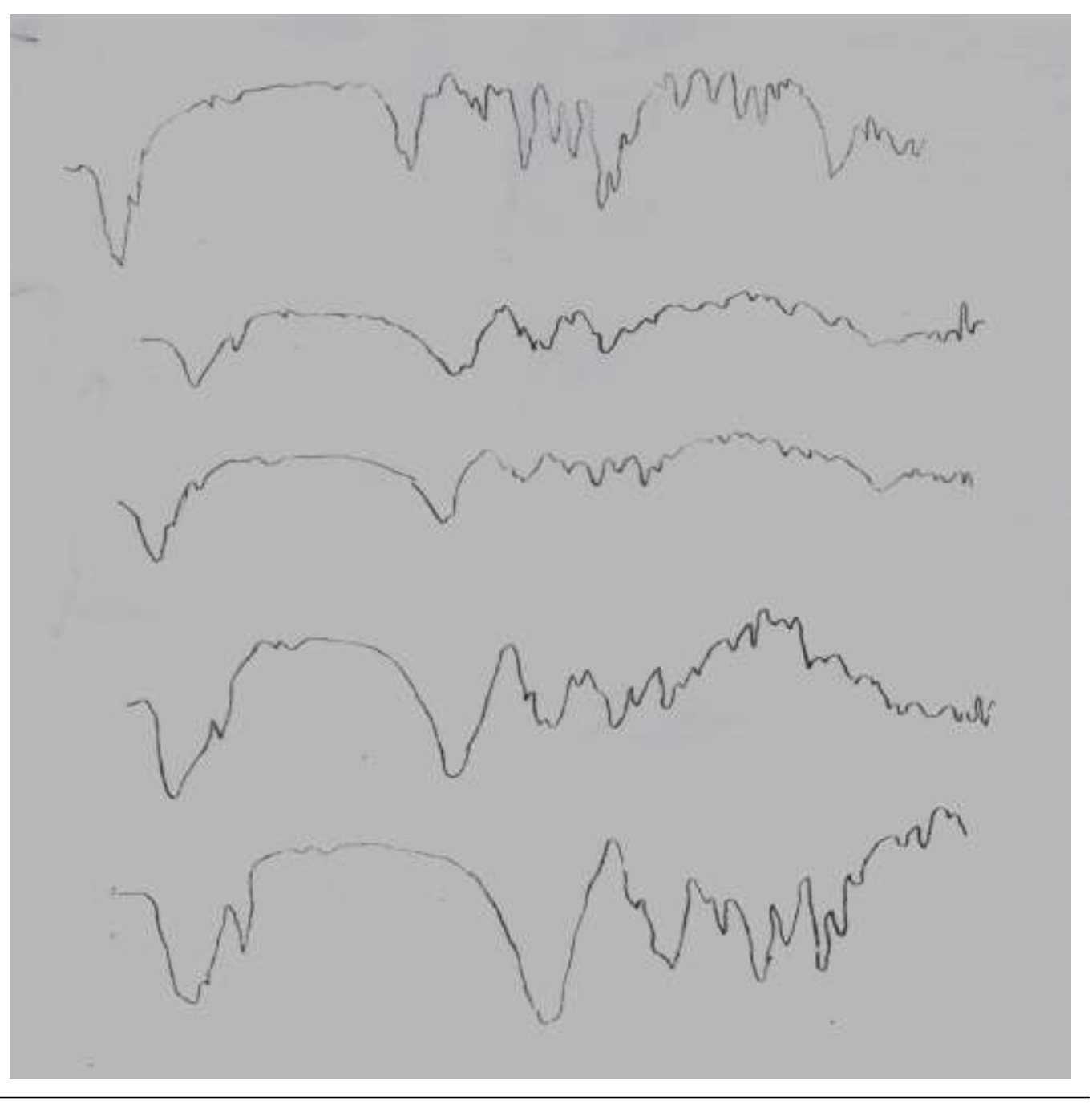

Figure (2): IR spectra of Celecoxib - Florite ${ }^{\circledR}$ prepared systems.

A- Drug alone.

B- Florite ${ }^{\circledR}$ alone.

C- Physical mixture of (1:5w/w drug: Florite ${ }^{\circledR}$ ratio).

D- Ground mixture of (1:5w/w drug: Florite ${ }^{\circledR}$ ratio).

E- Adsorbates (1:5w/w drug: Florite ${ }^{\circledR}$ ratio).

F- Co-adsorbate mixture of (1:3:5w/w drug: Tween 80 : Florite ${ }^{\circledR}$ ratio).

\subsection{2- Differential Scanning Calorimetric Studies}

Differential scanning calorimetry (DSC) has been used for characterization of the state of the drug and studying its interaction with carriers (Signoretti, et al., 1986). Figure (3) illustrates the thermograms of Celecoxib alone, Florite ${ }^{\circledR}$ alone its physical mixture, ground mixture, adsorbate and co-adsorbate with polysorbate 80 onto Florite $\AA$.

The DSC thermogram of Celecoxib (Trace F, Figure 3) shows a sharp endothermic peak at $160.37^{\circ} \mathrm{C}$ corresponding to its melting point of the drug with enthalpy change $(\Delta \mathrm{H})$ of $-90.76 \mathrm{~J} / \mathrm{g}$. Trace E of Figure (3) represents the DSC thermogram of Florite ${ }^{\circledR}$ alone, which is characterized by absence of any peaks within the temperature range employed $\left(30-200^{\circ} \mathrm{C}\right)$. This could be attributed to the inorganic nature of Florite ${ }^{\circledR}$ (Shaker et al., 1992).

In case of physical and ground mixtures of the drug with Florite ${ }^{\circledR}$, the drug endothermic peak at $160.37^{\circ} \mathrm{C}$ remained clearly detectable and maintained its shape with reduced intensity. This may be due to the dilution effect of the carrier in a ratio of $(1: 5 \mathrm{w} / \mathrm{w}$ drug: carrier). 
Figure (3) Trace C. shows the DSC thermogram of the adsorbate of Celecoxib onto Florite ${ }^{\circledR}$ at a ratio of (1:5 w/w drug: carrier). A very weak endothermic peak was observed for Celecoxib in its adsorbate, although the peak observed was a trace and the peak position was slightly shifted to lower temperature compared to the melting endothermic peak for pure drug. In general, the melting point of drug molecules in the pores is lower than that of bulk state (Etzler, 1987). (Nakai, 1984) reported this phenomenon with porous silica or porous cellulose as carriers in the mixing system of drug crystals and the porous materials.

Figure (3) Trace D, shows the coadsorbate of Celecoxib and polysorbate 80 onto Florite ${ }^{\circledR}$ at a ratio of $1: 3: 5 \mathrm{w} / \mathrm{w}$ drug: polysorbate 80 : Florite $\left.{ }^{\circledR}\right)$ polysorbate 80 being a liquid at the investigated temperature range, shows no significant peaks when adsorbed onto surface of Florite ${ }^{\circ}$.

DSC thermograms of the co-adsorbates of Celecoxib with polysorbate 80 onto Florite $\AA$ in a (1:5:5 w/w ratio) show complete disappearance of the endothermic peak of the drug at $160.37^{\circ} \mathrm{C}$ (Trace D, Figure 3). The loss of crystallinity of Celecoxib in its coadsorbates with porous calcium silicate (Florite $\left.{ }^{\circledR}\right)$ was explained in the view of the physical adsorption phenomena associated with drug silanol interaction within the inner pores of the silica matrix, adsorption may takes place via Van der Waal forces.

The DSC thermograms of co-adsorbate of Celecoxib with polysorbate 80 onto Florite ${ }^{\circledR}$ exhibited a complete disappearance of endothermic peak of the drug. Similar results were obtained by Hanawa et al., (1995) who reported that adsorption of ethenzamide onto porous calcium silicate (Florite $\left.{ }^{\circledR}\right)$ resulted in conversion of the drug to the amorphous state with disappearance of drug characteristic peak.

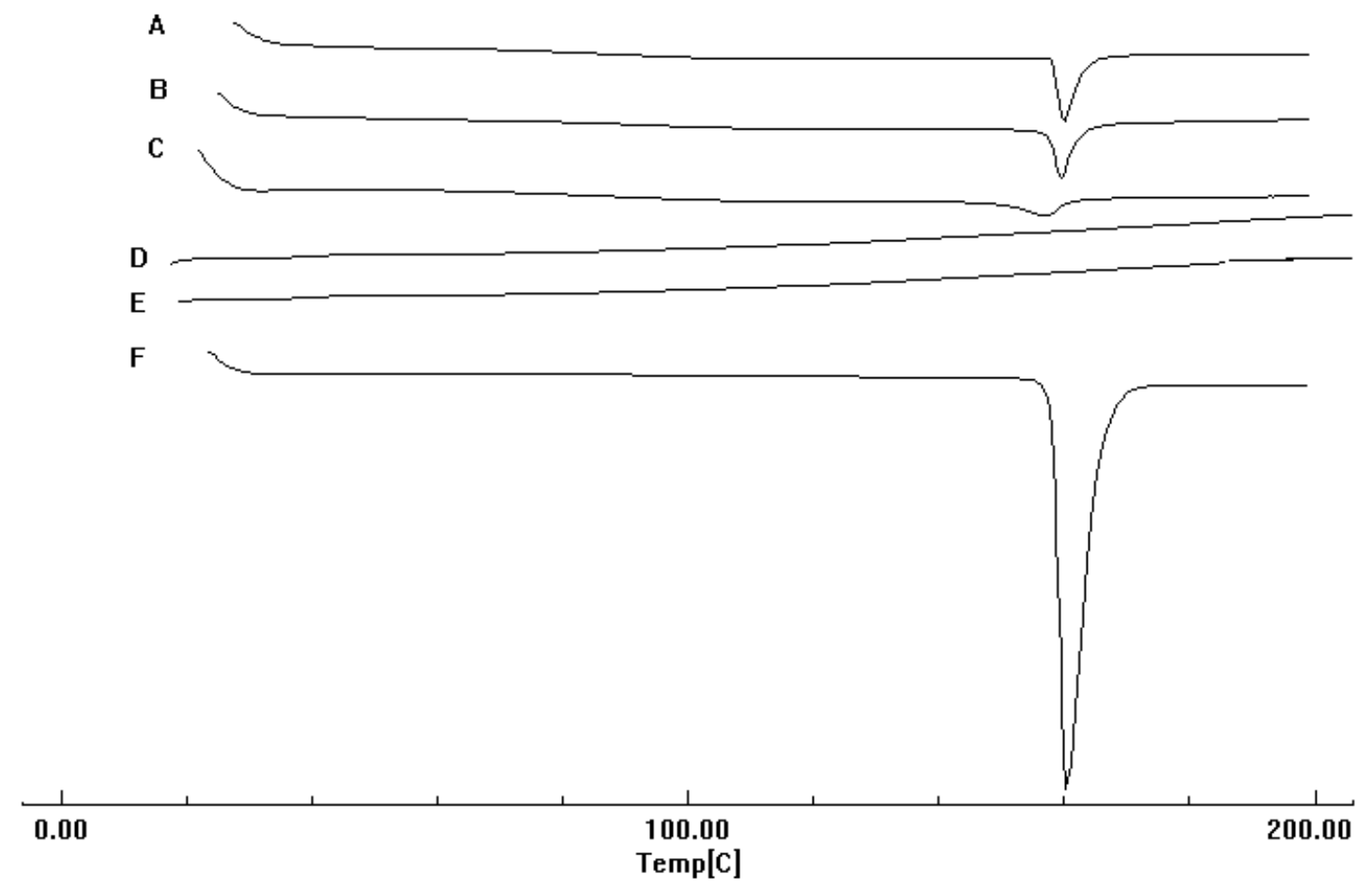

Figure (3): DSC thermograms of Celecoxib - Florite ${ }^{\circledR}$ in different prepared systems at a 1:5 w/w drug to carrier ratio.

(A) Physical mixture, (B) Ground mixture, (C) Adsorbate, (D) Co-adsorbate with polysorbate 80, (E) Florite ${ }^{\circledR}$ alone and (F) Drug alone.

2.1.3- X-Ray Diffraction Studies

Powder X-ray diffraction technique has been utilized to study the crystallographic nature of the different prepared systems of the drug with Florite ${ }^{\circledR}$. The X-ray diffraction 
patterns of Celecoxib, Florite $\AA$ as well as their corresponding ground, adsorbate in a ratio of (1:5 w/w drug: carrier) and co-adsorbate of (1:3:5 w/w drug: Tween 80: Florite $\AA)$ in comparison with the physical mixture at the same ratio, are presented in Figure (4).

Celecoxib shows crystalline structure with sharp characteristic peaks, particularly at $2 \theta$ of $6.09^{\circ}, 11.43^{\circ}, 15.53^{\circ}, 16.82^{\circ}, 22.25^{\circ}, 22.92^{\circ}, 27.72^{\circ}, 30.31^{\circ}$ and $33.27^{\circ}$ etc. (Figure 4, Trace A). Florite ${ }^{\circledR}$ shows characteristic peaks at $2 \theta$ of $43.61^{\circ}$ and $37.64^{\circ}$ (Figure 4, Trace B).

The crystallinity of Celecoxib in their physical and ground mixtures with Florite ${ }^{\circledR}$ remarkably decreased when compared with the pure drug. It may be attributed to dilution effect of Florite ${ }^{\circledR}$, as also indicated in DSC studies.

Significant reduction in peak intensities of Celecoxib was observed in powder x-ray diffraction pattern of adsorbates of the drug with Florite $\AA$ at a ratio of $(1: 5 \mathrm{w} / \mathrm{w}$ drug: carrier), probably of the rapid drying rate from methanol solution.

Co-adsorbate of Celecoxib with polysorbate 80 onto Florite ${ }^{\circledR}$ in a ratio of $1: 3: 5 \mathrm{w} / \mathrm{w}$ is shown in Figure 4, Trace C. Co-adsorbates of the drug exhibited a completely halo patterns with no diffraction peaks derived from Celecoxib observed.

The X-ray diffraction data indicated that Florite ${ }^{\circledR}$ has a greater ability to induce the transformation of Celecoxib to amorphous state in its co-adsorbates (1:3:5 w/w drug: polysorbate 80: Florite ${ }^{\circledR}$ ratio) than that in their ground and physical mixtures with Florite ${ }^{\circledR}$ (1:5 w/w drug: Florite $\left.{ }^{\circledR}\right)$. Therefore, both the amorphization and the decreased crystallinity of Celecoxib might be associated with hydrogen bonding between Celecoxib and the silanol group of Florite ${ }^{\circledR}$. Similar results are obtained by Takeuchi et al., (2005) who proved that indomethacin converted into amorphous state in their solid dispersion particles using fine porous silica.

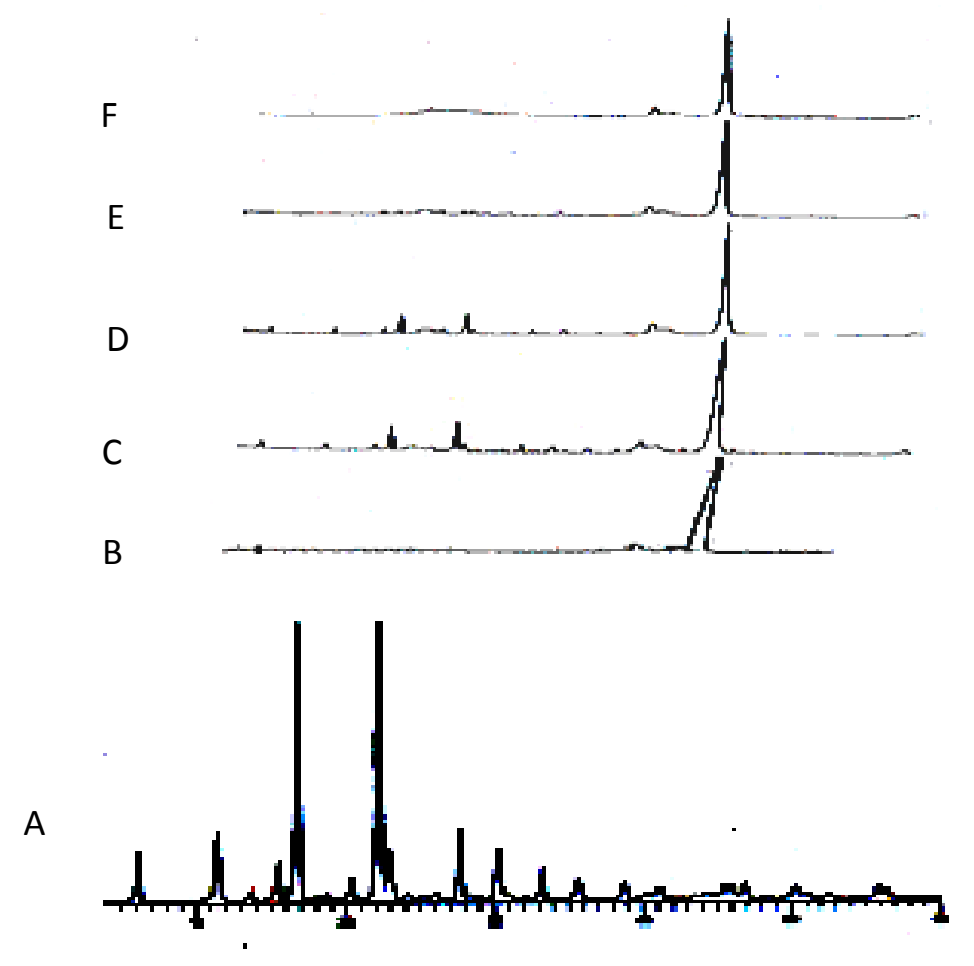

Figure (4): Powder X-ray diffractograms of Celecoxib - Florite ${ }^{\circledR}$ in the different prepared systems.
A- Drug alone.
B- Florite $®$ alone.
C- Physical mixture of (1:5 w/w drug: Florite ${ }^{\circledR}$ ratio) $\quad$ D- Ground mixture of (1:5 w/w drug: Florite ${ }^{\circledR}$ ratio)
E- Adsorbate mixture of (1:5 w/w drug: Florite ${ }^{\circledR}$ ratio)
F- Co-adsorbate mixture of (1:3:5 w/w drug: polysorbate 80 : Florite $\left.{ }^{\circledR}\right)$ 


\section{2- In Vitro Dissolution Studies from Celecoxib Adsorbate and Co-adsorbate:}

The effect of different ratios of Florite ${ }^{\circledR}$ or Aerosil 200 on the release behavior of Celecoxib from various systems prepared by different techniques is shown in Tables $(7 \& 8)$. It is obvious that, the rate of Celecoxib dissolution varies with the nature of the material components and surface area, the ratio of drug to adsorbent, and the methods by which the loaded mixtures were prepared.

The dissolution rate of Celecoxib from various systems decreased in the following order: adsorbates $>$ grinding systems $>$ physical mixtures $>$ pure drug. Physical and ground mixtures of Celecoxib with either Florite ${ }^{\circledR}$ or Aerosil 200 show slightly higher drug release than that drug alone. Increasing the concentration of the used carrier from the ratio of 1:1 to 1:5 w/w (drug: carrier) led to increase the dissolution rate of the drug from these prepared systems. It is found that the dissolution rate of Celecoxib solvent deposited onto Florite ${ }^{\circledR}$ is higher than those with Aerosil 200.

The adsorbates of Celecoxib with Florite ${ }^{\circledR}$ dissoluted $21.7 \%$ of the drug, while the corresponding adsorbates with Aerosil 200 released only $15.8 \%$ of the drug using the same ratio after the same time (Table $7 \& 8$ ).

Silicates are of outstanding importance in pharmaceutical formulations as carriers in solid, semisolid and liquid dosage forms due to their excellent physicochemical properties. Florite ${ }^{\circledR}$ is porous calcium silicate. It has extensive surface area $\left(140 \mathrm{~m}^{2} / \mathrm{g}\right)$, good flowability and excellent mouldability. Moreover, it is a pure synthetic inorganic unabsorbable material so that it is considered safe for oral administration. Molecular dispersions of drugs onto the extremely large surface of porous silica have been utilized for improving dissolution rates and absorption of several poor water soluble drugs.

It is clear that both solvent deposited systems and ground mixtures demonstrate a marked increase in the release rate of Celecoxib than that of physical mixtures or drug alone with either Florite ${ }^{\circledR}$ or Aerosil 200. The higher dissolution rate of Celecoxib in these prepared systems could be explained in view of rapid desorption of the physically adsorbed drug molecules when these mixtures are placed into the dissolution medium. Thus the drug molecules released simultaneously into the dissolution medium. The dissolution mechanism is therefore different from that of physical mixture where dissolution occurs from the surface of the drug crystals according to concentration gradient.

The dissolution rates of Celecoxib from their co-adsorbate systems with polysorbate 80 onto surface of Florite ${ }^{\circledR}$ or Aerosil 200 are shown in Table (9), and graphically represented by Figures ( $5 \mathrm{~A} \& \mathrm{~B})$. The co-adsorbates were prepared by solvent deposition method using drugto-surfactant to adsorbent at ratios of (1:1:5, 1:3:5 and 1:5:5 w/w, respectively).

It is found that increasing the concentration of surfactant in the co-adsorbate results in obvious enhancement in drug dissolution rate. The possible explanation for this effect is that surfactants can be adsorbed on the surface of solid carriers leading to the formation of aggregates called "admicelles". These aggregates can incorporate hydrophobic drug molecules in their cores resulting in the phenomenon of ad-solubilization or co-adsorption (Cherkaoui et al., 2000).

Buckton et al., (1991) shown that the rate of drug release can be much increased by the presence of surfactants at the solid surfaces as a third component system. The increased wettability of the surface of the solid particles may also be an important parameter in drug release investigation.

Co-adsorbates prepared using Florite ${ }^{\circledR}$ as an adsorbent as a carrier show higher dissolution rates compared with those prepared using Aerosil 200. Co-adsorbate of the drug with Tween 80 onto Florite ${ }^{\circledR}$ released $100 \%$ of the drug after 30 min., while $19.93 \%$ drug released from co-adsorbate of the drug with Tween 80 onto Aerosil 200 after the same period. 
This may reflect the highly porous structure and adsorption capacity of porous calcium silicate (Florite ${ }^{\circledR}$ ) compared with silicon dioxide (Aerosil 200) (Hanawa et al., 1997).

Table (7): Percentage of Celecoxib Released from the Prepared Physical mixture, Ground Mixtures and Adsorbates onto Florite ${ }^{\circledR}$ at $\mathrm{pH} 1.2$

\begin{tabular}{|c|c|c|c|c|c|c|c|c|c|c|}
\hline \multirow{3}{*}{$\begin{array}{l}\text { Time } \\
\text { (min.) }\end{array}$} & \multicolumn{10}{|c|}{ Percentage of Celecoxib Released } \\
\hline & \multirow{2}{*}{$\begin{array}{l}\text { Drug } \\
\text { alone }\end{array}$} & \multicolumn{3}{|c|}{$\begin{array}{l}\text { Physical mixtures } \\
\text { (Drug: Florite } ® \text { w/w) }\end{array}$} & \multicolumn{3}{|c|}{$\begin{array}{l}\text { Adsorbates } \\
\text { (Drug: Florite } \mathbb{w} / w \text { ) }\end{array}$} & \multicolumn{3}{|c|}{$\begin{array}{l}\text { Ground mixtures } \\
\text { (Drug: Florite® w/w) }\end{array}$} \\
\hline & & $(1: 1)$ & $(1: 3$ & $(1: 5)$ & $(1: 1)$ & $(1: 3)$ & $(1: 5)$ & $(1: 1)$ & $(1: 3)$ & $(1: 5)$ \\
\hline 15 & 0.66 & 0.85 & 3.52 & 3.69 & 5.28 & 8.29 & 11.36 & 1.33 & 9.031 & 9.76 \\
\hline 30 & 0.73 & 2.42 & 4.13 & 4.54 & 7.23 & 9.25 & 13.28 & 5.11 & 10.62 & 11.07 \\
\hline 45 & 1.47 & 3.69 & 6.11 & 6.38 & 9.62 & 10.96 & 15.44 & 5.83 & 10.83 & 11.49 \\
\hline 60 & 2.21 & 4.45 & 6.34 & 6.54 & 9.86 & 13.23 & 15.79 & 7.72 & 11.55 & 11.93 \\
\hline 90 & 2.96 & 7.04 & 6.57 & 8.19 & 12.07 & 14.99 & 16.09 & 8.16 & 12.13 & 15.80 \\
\hline 120 & 3.71 & 7.43 & 7.41 & 8.62 & 13.24 & 16.48 & 21.7 & 8.63 & 12.78 & 16.22 \\
\hline
\end{tabular}

Table (8): Percentage of Celecoxib Released from the Prepared Physical Mixture, Ground Mixtures and Adsorbates with Aerosil 200 at $\mathrm{pH} 1.2$

\begin{tabular}{|c|c|c|c|c|c|c|c|c|c|c|}
\hline \multirow{3}{*}{$\begin{array}{l}\text { Time } \\
\text { (min.) }\end{array}$} & \multicolumn{10}{|c|}{ Percentage of Celecoxib Released } \\
\hline & \multirow{2}{*}{$\begin{array}{l}\text { Drug } \\
\text { alone }\end{array}$} & \multicolumn{3}{|c|}{$\begin{array}{l}\text { Physical mixtures } \\
\text { (Drug: Aerosil } 200 \text { w/w) }\end{array}$} & \multicolumn{3}{|c|}{$\begin{array}{l}\begin{array}{l}\text { Adsorbates } \\
\text { (Drug: Aerosil } 200 \text { w/w) }\end{array} \\
\end{array}$} & \multicolumn{3}{|c|}{$\begin{array}{l}\text { Ground mixtures } \\
\text { (Drug: Aerosil } 200 \text { w/w) }\end{array}$} \\
\hline & & $(1: 1)$ & $(1: 3)$ & $(1: 5)$ & $(1: 1)$ & $(1: 3)$ & $(1: 5)$ & $(1: 1)$ & $(1: 3)$ & $(1: 5)$ \\
\hline 15 & 0.66 & 0.88 & 1.11 & 6.53 & 2.93 & 8.07 & 11.08 & 9.47 & 9.911 & 10.79 \\
\hline 30 & 0.73 & 1.25 & 5.07 & 7.32 & 6.33 & 9.59 & 13.75 & 11.36 & 11.43 & 12.16 \\
\hline 45 & 1.47 & 2.21 & 5.36 & 11.83 & 9.23 & 11.48 & 14.09 & 11.44 & 12.01 & 13.19 \\
\hline 60 & 2.21 & 3.33 & 6.11 & 12.72 & 10.38 & 12.27 & 14.38 & 11.75 & 12.66 & 13.40 \\
\hline 90 & 2.96 & 3.72 & 6.55 & 13.48 & 11.22 & 13.44 & 15.34 & 12.94 & 13.25 & 13.85 \\
\hline 120 & 3.71 & 4.56 & 7.14 & 13.77 & 11.65 & 14.55 & 15.8 & 13.72 & 13.44 & 14.42 \\
\hline
\end{tabular}

Table (9): Percentage of Celecoxib Released from the Prepared Co-adsorbate Mixtures with Polysorbate 80 with Florite ${ }^{\circledR}$ and Aerosil 200 at $\mathrm{pH}$ 1.2.

\begin{tabular}{|c|c|c|c|c|c|c|c|}
\hline \multirow{3}{*}{$\begin{array}{l}\text { TIME } \\
\text { (MIN.) }\end{array}$} & \multicolumn{7}{|c|}{ Percentage of Celecoxib Released } \\
\hline & \multirow[t]{2}{*}{$\begin{array}{l}\text { Drug } \\
\text { alone }\end{array}$} & \multicolumn{3}{|c|}{$\begin{array}{l}\text { Co-adsorbate } \\
\text { (Drug: polysorbate 80: Florite } \AA \\
\text { w/w) }\end{array}$} & \multicolumn{3}{|c|}{$\begin{array}{l}\text { Co-adsorbate } \\
\text { (Drug: polysorbate 80: Aerosil } \\
200 \text { w/w) }\end{array}$} \\
\hline & & $(1: 1: 5)$ & $(1: 3: 5)$ & $(1: 5: 5)$ & $(1: 1: 5)$ & $(1: 3: 5)$ & $(1: 5: 5)$ \\
\hline 15 & 0.66 & 35.81 & 97.23 & 79.21 & 2.74 & 19.34 & 315.98 \\
\hline 30 & 0.73 & 39.22 & 100.02 & 94.14 & 2.85 & 19.91 & 38.62 \\
\hline 45 & 1.47 & 43.47 & 100.66 & 97.93 & 5.90 & 21.06 & 40.83 \\
\hline 60 & 2.21 & 42.31 & 101.43 & 100.84 & 8.87 & 23.17 & 41.76 \\
\hline 90 & 2.96 & 43.44 & 102.04 & 101.82 & 11.66 & 23.96 & 42.45 \\
\hline 120 & 3.71 & 45.28 & 102.32 & 102.48 & 14.94 & 24.82 & 42.95 \\
\hline
\end{tabular}




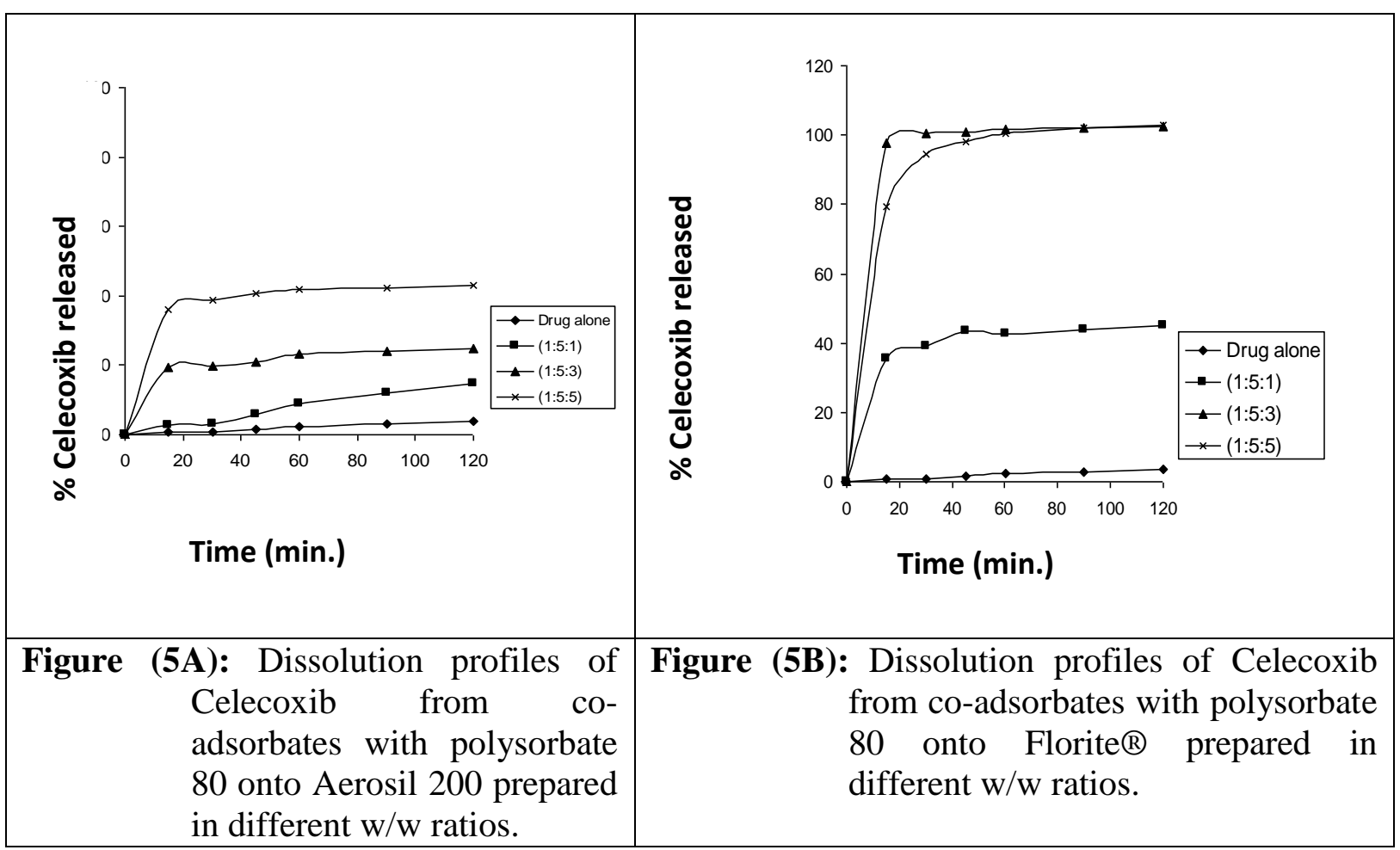

\section{Celecoxib Co-adsorbate Floating Capsules}

Floating capsules were formulated according to composition tabulated in table (2). Coadsorbate of Celecoxib with Florite ${ }^{\circledR}$ and polysorbate 80 because the percentage of drug release obtained from this co-adsorbate was higher than Aerosil 200 and polysorbate 80 coadsorbate in the selected ratio.

\section{1- Floating Behavior of Celecoxib Co-adsorbate Floating Capsules}

Table (10) showed the floating properties of Celecoxib capsule formulae (C1-C6) in $\mathrm{pH} 1.2$ buffered solutions. The floating time is the time for the capsule to remain buoyant on the gastric fluid. All the prepared formulae of Celecoxib capsules immediately floated on the surface of the dissolution medium. After the hard gelatin gel dissolved, the contents of the capsule adhered together forming a single unit that continued to float and swell till the end of the time ( 8 hours). During this time, Celecoxib diffused through the co-adhered matrix to be released in the dissolution medium.

Hydroxypropyl methylcellulose (HPMC $4000 \mathrm{cps}$.) is responsible for the floating properties of the dosage forms. When come in contact with gastric fluid, it swells forming a hydrocolloid that has a bulk density lower than that of the gastric fluid and remains therefore buoyant on the stomach contents. Decreasing the concentration of HPMC 4000 from $50 \mathrm{mg}$ in capsule (C5) to $25 \mathrm{mg}$ in capsule (C1) led to a marked decrease in the floating time of the capsule from 8 hrs to $5.30 \mathrm{hrs}$, (Table 10).

Florite ${ }^{\circledR}$ (porous calcium silicate) has a characteristic porous structure and very low density. It has been used for the development of intragastric floating and sustained-release preparations. The floating ability of Florite ${ }^{\circledR}$ results from the air trapped in the porous structure of calcium silicate (Yuasa et al., 1996). It was found that the preliminary adsorption of the drug to surface of Florite ${ }^{\circledR}$ resulted in enhancement of the floating properties of the capsules. These results are in agreement with Yuasa et al., (1996) who reported that the use of Florite ${ }^{\circledR}$ in the intragastric diclofenac sodium granules produced a prolonged floating time.

The prepared floating capsules (C5) showed the best floating behaviors followed by formula (C4) as illustrated in table (10) thus can be explained by the inclusion of highest amount of HPMC 4000 in capsule (C5) and highest ratio of florite in formula C4 and C5 (1:5) w/w drug Florite ${ }^{\circledR}$. 
Table (10): Floating Properties of the Prepared Capsules of Celecoxib Co-adsorbate $\left(\mathrm{C}_{1}-\mathrm{C}_{6}\right)$.

\begin{tabular}{|c|c|c|}
\hline Formula & Floating time & Description \\
\hline $\mathrm{C}_{1}$ & $\begin{array}{l}5 \text { hours and } \\
30 \text { minutes }\end{array}$ & $\begin{array}{l}\text { - The capsule first took its definite shape, then after the } \\
\text { stated timer the contents of the capsule dispersed and some } \\
\text { of the particles remained floating. } \\
\text { - The solution was quiet turbid. }\end{array}$ \\
\hline $\mathrm{C}_{2}$ & 6 hours & $\begin{array}{l}\text { - The hard gelatin capsule first took its definite shape then } \\
\text { after the stated time، the contents of the capsule dispersed } \\
\text { and some of the particles remained floating. } \\
\text { - The solution was more turbid than that of } C_{1} \text {. }\end{array}$ \\
\hline $\mathrm{C}_{3}$ & $\begin{array}{l}6 \text { hours and } \\
15 \text { minutes }\end{array}$ & $\begin{array}{l}\text { - The hard gelatin capsule first took its definite shape then } \\
\text { after the stated time، the contents of the capsule dispersed } \\
\text { and some of the particles remained floating. } \\
\text { - The solution was more turbid than that of } \mathrm{C}_{2} \text {. }\end{array}$ \\
\hline $\mathrm{C}_{4}$ & $\begin{array}{l}6 \text { hours and } \\
40 \text { minutes }\end{array}$ & $\begin{array}{l}\text { - The hard gelatin capsule first took its definite shape then } \\
\text { after the stated time' the contents of the capsule dispersed } \\
\text { and some of the particles remained floating. } \\
\text { - The solution was more turbid than that of } C_{3} \text {. }\end{array}$ \\
\hline $\mathrm{C}_{5}$ & $\begin{array}{l}\text { All the time } \\
\text { ( } 8 \text { hours) }\end{array}$ & $\begin{array}{l}\text { - The contents of the capsule did not rupture and retained its } \\
\text { definite shape while floating absorption of water caused the } \\
\text { capsule to increase in size and take the shape of a gelatinous } \\
\text { mass structure. } \\
\text { - The solution was clear. }\end{array}$ \\
\hline $\mathrm{C}_{6}$ & $\begin{array}{l}5 \text { hours and } \\
45 \text { minutes }\end{array}$ & $\begin{array}{l}\text { - The hard gelatin capsule first took its definite shaper then } \\
\text { after the stated timer the contents of the capsule dispersed } \\
\text { and some of the particles remained floating. } \\
\text { - The solution was highly turbid. }\end{array}$ \\
\hline
\end{tabular}

\section{2- In-Vitro Drug Release Study of the Prepared Floating Capsules of Celecoxib Co- adsorbate}

Table (11) and Figures (6 A\&B) showed the dissolution behavior of Celecoxib from the prepared floating Celecoxib Co-adsorbate capsules (C1-C6) in $0.1 \mathrm{~N} \mathrm{HCl}$ (pH 1.2). Coadsorbate of the drug with polysorbate 80 onto surface of Florite ${ }^{\circledR}$ were prepared by solvent deposition method, to enhance the solubility and dissolution of Celecoxib in gastric medium ( $\mathrm{pH}$ 1.2). Thus, controlled release limited by drug dissolution was precluded and delivery of Celecoxib was controlled by the formulation.

Figure (6 A) illustrates the effect of different ratios of co-adsorbate on Celecoxib release from formulae (C1-C4) containing the same amount of HPMC 4000 (25 mg) and anhydrous Lactose as a filler. The release of Celecoxib from its floating capsules containing different coadsorbate ratios was decreased in the following order: 1:5:3 > 1:3:5 > 1:2:3> 1:1:1 w/w (drug: Florite®: polysorbate 80 ). The percentage released of Celecoxib from the best ratio of coadsorbate (1:5:3) reached nearly $96.63 \%$ after 8 hours. The possible explanation for this effect is that surfactants are adsorbed on the surface of solid carriers leading to the formation of aggregates called "admicelles". These aggregates can incorporate hydrophobic drug molecules in their cores resulting in the phenomenon of adsolubilization or coadsorption (Cherkaoui et al., 2000). Increased wettability of the surface of the solid carrier by the presence of surfactant molecules as a third component system was taken as an important parameter in drug release investigation (Buckton et al., 1991). 
Figure (6 B) shows the effect of different concentrations of HPMC 4000 on Celecoxib release from formulae (C4-C6) respectively containing the same ratio of coadsorbate (1:5:3 w/w of drug: Florite ${ }^{\circledR}$ : polysorbate 80 ) and anhydrous Lactose as a filler. Increasing the amount of HPMC from 12.5 to $50 \mathrm{mg}$ in capsules (C6 to C5) led to a marked decrease in the percentage released of Celecoxib from $96.63 \%$ to $60.21 \%$. The highest release rate of Celecoxib from formula (C6) containing $12.5 \mathrm{mg}$ HPMC can be attributed to drug dissolution from coadsorbate particles uncovered with the polymer in this low concentration (Yuasa $\boldsymbol{e t}$ al., 1996).

Table (11): Percentage Released of Celecoxib Adsorbate from the Different Prepared Floating Capsules at $\mathrm{pH} 1.2$

\begin{tabular}{|l|l|l|l|l|l|l|}
\hline \multirow{2}{*}{$\begin{array}{c}\text { Formula No. } \\
\text { Time (min) }\end{array}$} & \multicolumn{5}{|l|}{ Percentage of Celecoxib released after the specified time } \\
\cline { 2 - 7 } & $\mathbf{C 1}$ & $\mathbf{C 2}$ & $\mathbf{C 3}$ & $\mathbf{C 4}$ & $\mathbf{C 5}$ & C6 \\
\hline 15 & $19.85 \pm 2.4$ & $28.29 \pm 1.8$ & $31.25 \pm 3.8$ & $39.62 \pm 2.6$ & $23.22 \pm 1.1$ & $41.39 \pm 2.5$ \\
\hline 30 & $21.24 \pm 3.5$ & $30.26 \pm 2.3$ & $34.23 \pm 2.9$ & $44.71 \pm 3.2$ & $28.11 \pm 3.2$ & $48.52 \pm 3.6$ \\
\hline 60 & $25.36 \pm 4.1$ & $34.22 \pm 5.2$ & $37.52 \pm 1.6$ & $48.51 \pm 6.4$ & $31.29 \pm 4.1$ & $56.26 \pm 3.3$ \\
\hline 90 & $28.54 \pm 2.3$ & $37.21 \pm 4.3$ & $39.66 \pm 2.3$ & $51.61 \pm 4.1$ & $35.30 \pm 3.2$ & $60.24 \pm 4.6$ \\
\hline 120 & $30.98 \pm 5.6$ & $40.11 \pm 4.2$ & $42.71 \pm 3.1$ & $57.82 \pm 5.8$ & $39.36 \pm 4.8$ & $66.62 \pm 3.1$ \\
\hline 150 & $34.81 \pm 3.5$ & $42.91 \pm 4.7$ & $50.01 \pm 4.8$ & $62.56 \pm 5.6$ & $42.29 \pm 3.1$ & $72.76 \pm 3.7$ \\
\hline 180 & $36.25 \pm 2.2$ & $48.21 \pm 2.4$ & $54.26 \pm 3.9$ & $69.43 \pm 3.4$ & $44.34 \pm 2.1$ & $80.91 \pm 6.3$ \\
\hline 240 & $37.81 \pm 4.3$ & $52.41 \pm 6.5$ & $59.18 \pm 3.1$ & $71.27 \pm 2.7$ & $47.24 \pm 3.6$ & $84.82 \pm 2.2$ \\
\hline 300 & $39.21 \pm 3.6$ & $58.71 \pm 3.5$ & $62.67 \pm 4.3$ & $77.87 \pm 1.3$ & $48.92 \pm 1.9$ & $87.51 \pm 4.8$ \\
\hline 360 & $40.82 \pm 3.7$ & $60.42 \pm 3.1$ & $67.03 \pm 3.3$ & $80.33 \pm 6.4$ & $53.57 \pm 3.8$ & $90.33 \pm 3.9$ \\
\hline 420 & $48.52 \pm 3.8$ & $62.62 \pm 3.8$ & $70.33 \pm 2.3$ & $82.76 \pm 3.3$ & $57.89 \pm 4.3$ & $93.13 \pm 3.7$ \\
\hline 480 & $52.57 \pm 4.2$ & $66.21 \pm 4.4$ & $74.61 \pm 4.1$ & $85.31 \pm 2.2$ & $60.22 \pm 1.1$ & $96.63 \pm 4.7$ \\
\hline
\end{tabular}

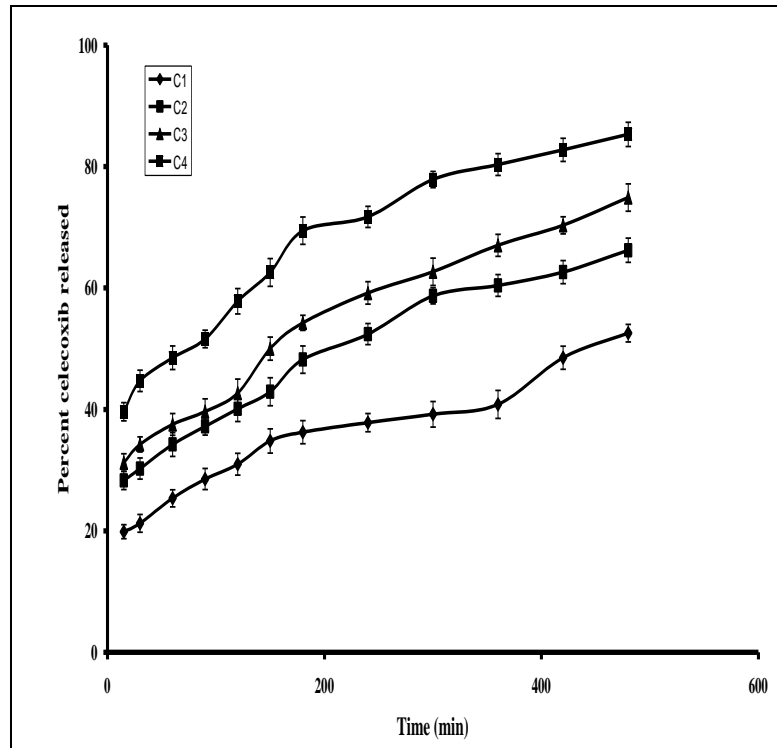

Figure (6 A): In-vitro release of Celecoxib Coadsorbate floating capsules (C1-C4)

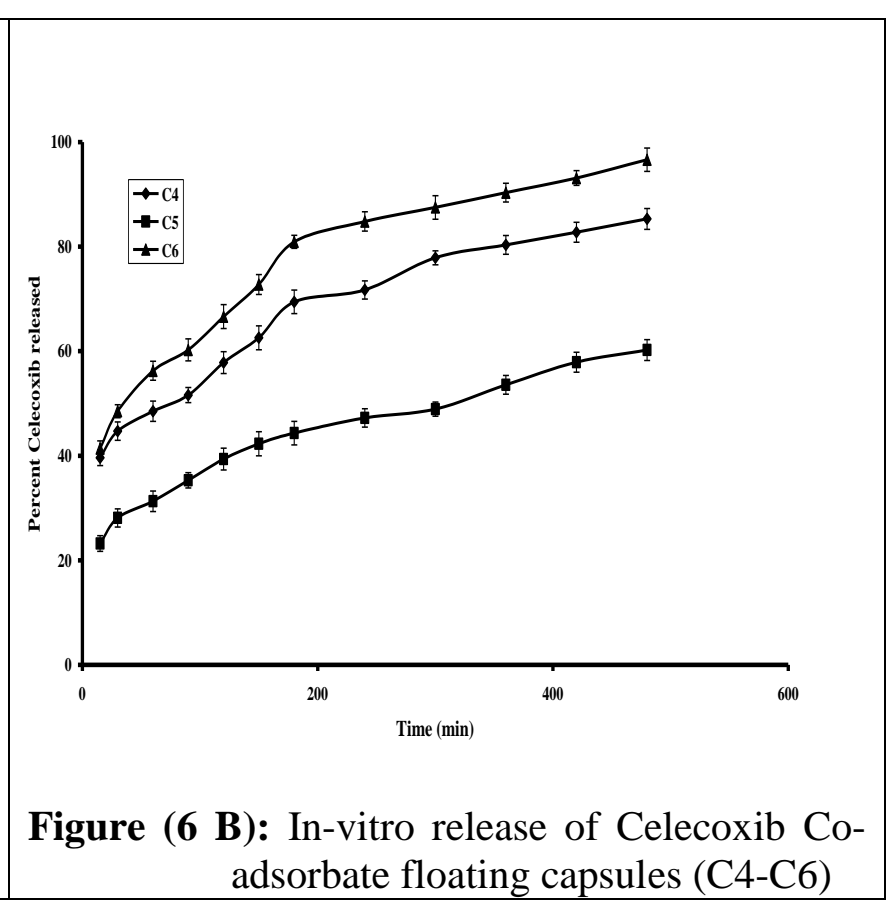
adsorbate floating capsules (C4-C6)

\section{3- Investigation of Celecoxib Release Kinetics}

The mechanism of the drug release from Co-adsorbate floating capsules was investigated as mentioned above. Table (12) show calculated correlation coefficient for the invitro release of Celecoxib Co-adsorbate floating capsules. There is no one definite kinetic 
model can express the release of the drug from the capsules, According to the obtained results, drug release from the capsules can be described by different kinetic models (zero, first or Higuchi diffusion model) through the highest calculated correlation coefficient.

Table (12): The Calculated Correlation Coefficients for the In-Vitro Release of Celecoxib Floating Capsules at pH 1.2 Employing Different Kinetic Orders.

\begin{tabular}{|l|l|l|l|}
\hline \multirow{2}{*}{ Formula No. } & \multicolumn{3}{|l|}{ Correlation Coefficients (r) } \\
\cline { 2 - 4 } & Zero-order & First-order & $\begin{array}{l}\text { Higuchi's diffusion } \\
\text { model }\end{array}$ \\
\hline C1 & 0.974108 & 0.977870 & $\mathbf{0 . 9 8 3 2 4 1}$ \\
\hline C2 & 0.98305 & 0.993889 & $\mathbf{0 . 9 9 4 1 3 3}$ \\
\hline C3 & 0.983786 & $\mathbf{0 . 9 9 6 3 8 0}$ & 0.992076 \\
\hline C4 & 0.963923 & $\mathbf{0 . 9 9 3 2 6 0}$ & 0.991780 \\
\hline C5 & 0.972835 & 0.993772 & $\mathbf{0 . 9 9 6 2 7 1}$ \\
\hline C6 & 0.940661 & 0.880718 & $\mathbf{0 . 9 8 5 3 8 4}$ \\
\hline
\end{tabular}

\section{CONCLUSION}

From the previous results, DSC and IR analysis proved that Celecoxib is compatible with HPMC 4000cps, NaCMC, sodium bicarbonate, anhydrous lactose, and magnesium stearate. Thus, these excipients can be used in the formulation of Celecoxib floating capsules. Co-adsorbate of Celecoxib with polysorbate 80 onto Florite ${ }^{\circledR}$ at the ratios of $(1: 3: 5 \mathrm{w} / \mathrm{w}$ and 1:5:5 drug: Polysorbate 80: Florite $\left.{ }^{\circledR}\right)$ gave the highest percentage of Celecoxib released (reached about $100 \%$ after 15 and $45 \mathrm{~min}$; respectively). Floating casuples containing this drug co-adsorbate in ratio of 1:5:3 w/w of drug: Florite ${ }^{\circledR}$ : polysorbate 80 showed the highest release rates of Celecoxib. Finally formula of Celecoxib floating capsule containing (coadsorbate in 1:5:3 w/w of drug: Florite ${ }^{\circledR}$ : polysorbate $80,12.5 \mathrm{mg}$ of HPMC 4000, $10.5 \mathrm{mg}$ of sodium bicarbonate, $3.5 \mathrm{mg}$ magnesium stearate and $98.5 \mathrm{mg}$ of anhydrous lactose) is recommended. This formula gave the highest drug release $(96.63 \%)$ and accepted floating time (around 6 hours).

\section{REFERENCES}

Arza R.A., Gonugunta C.S. and Veerareddy P.R., (2009): Formulation and evaluation of swellable and floating gastroretentive ciprofloxacin hydrochloride tablets, AAPS PharmSciTech. 10 (1) 220-226.

Basak, S.R., Rahman, J., Ramalingm, M., (2007): Design and in vitro testing of a floatable gastroretentive tablet of metformin hydrochloride. Pharmazie 62 (2), 145-148.

Berner, B., Louie-Helm, J., (2002): Tablet shapes to enhance gastric retention of swellable controlled-release oral dosage forms, US Patent 6,488,962 (December 3).

Buckton, G., Efentakis, M., Al-Hamoud, H., and Rajan, Z., (1991): Int. J. Pharm., 74, 169.

Chacon, M., Molpeceres, J., Berges, L., Guzman, M., and Aberturas, (2006): Characterization of ciprofloxacin floating and bioadhesive extended-release tablets, Drug Deliv. 13 (4) 277-285.

Chavanpatil M.D., Jain P., Chaudhari S., Shear R. and Vavia R.R., (2006): Novel sustained release, swellable and bioadhesive gastroretentive drug delivery system for ofloxacin, Int. J. Pharm. 316 (1-2) 86-92. 
Chavanpatil, M.D., Jain, P., Chaudhari, S., Shear, R., Vavia, P.R., (2006): Novel sustained release, swellable and bioadhesive gastroretentive drug delivery system for ofloxacin. Int. J. Pharm. 316, 86-92.

Chen, J., Park, K., (2000a): Synthesis and characterization of superporous hydrogel composites. J. Control. Release 65, 73-82.

Chen, J., Park, K., (2000b): Synthesis of fast-swelling, superporous sucrose hydrogels. Carbohydr. Polym. 41, 259-268.

Cherkaoui, I., Monicone, V., Vaution, C., and Treiner, C., (2000): Int. J. Pharm., 201, 71.

Deshpande A.A., Shah N.H., Rhodes C.T., Malick W., (1997): Development of a novel controlled release system for gastric retention, Pharm. Res. 14 (1997) 815-819.

Dua, K., Ramana M., and Himaja., (2007): Control Drug Del., 4, 21.

Etzler F.M. and White P.J., (1987): J. Colloid. Interf. Sci. 120, 94.

Garg R. and Gupta G.D., (2008): Progress in controlled gastroretentive delivery systems, Trop. J. Pharm. Res. 7 (3) 1055-1066.

Gerogiannis V. S., Rekkas D. N., Dallas, P. P., and Choulis, N. H., (1993): Drug Dev. Ind. Pharm., 19, 1061.

Hanaw, T., Ikoma R., Watanabe A., Sugihara M. and Yamamoto, K., (1995): Japanese J. Hop. Pharm., 21, 1.

Hong S. S., Lee S. H., Lee Y. J., Chung S. J., Lee M. H., and Shim C. K., (1998): J. Control. Release., 51, 185.

Hwang S.J., Park H. and Park K., (1998): Gastric retentive drug-delivery systems, Crit. Rev. Ther. Drug Carrier Syst. 15 (3) 243-284.

Iannuccelli V., Coppi G., Bernabei M.T. and Cameroni R., (1998): Air compartment multiple-unit system for prolonged gastric residence. Int. J. Pharm. 174, 47-54.

Ingani H. M., Timmermans J. and Moes A. J., (1987): Int. J. Pharm., 35, 157.

Jain S.K., Awasthi A.M., Jain N.K. and Agrawal G.P., (2005): Calcium silicate based microspheres of repaglinide for gastroretentive floating drug delivery: preparation and in vitro characterization, J. Control. Release 107, pp. 300-309.

Jimenez-Castellanos M.R., Zia H. and Rhodes C.T., (1994): Design and testing in vitro of a bioadhesive and floating drug delivery system for oral application. Int. J. Pharm. $105,65-70$.

Jimenez-Martinez I., Quirino-Barreda T. and Villafuerte-Robles V., (2008): Sustained delivery of captopril from floating matrix tablets. Int. J. Pharm. 362, 37-43.

Klausner E.A., Lavy E., Stepensky D., Friedman M. and Hoffman A., (2002): Novel gastroretentive dosage forms: evaluation of gastroretentivity and its effect on riboflavin absorption in dogs. Pharm. Res. 19, 1516-1523.

Klausner E.A., Lavy E., Barta M. Cserepes E., Friedman M. and Hoffman A., (2003): Novel gastroretentive dosage forms: evaluation of gastroretentivity and its effect on levodopa absorption in humans. Pharm. Res. 20, 1466-1473.

Lee C.R., Pieper J.A., Hinderliter A.L., Blaisdell J.A., Goldstein J.A. and Losartan, (2003): E3174 pharmacokinetics in cytochrome P450 2C9*1/*1, *1/*2, and *1/*3 individuals. Pharmacotherapy 23, 720-725.

M. R., (1999): Eur. J. Pharm. Sci., 8, 99.

M. S., (1989): Bull. Pharm. Sci., Assiut Univ., 12, 175.

Monkhouse D. C. and Lach J. L., (1972): J. Pharm. Sci., 61, 1430. 
Monticone V. and Treiner C., (1995): Coll. Surf., 104, 285.

Munday D.L., (2003): Film coated pellets containing verapamil hydrochloride: enhanced dissolution into neutral medium, Drug Dev. Ind. Pharm. 29 pp. 575-583.

Nakai Y., Yamamoto K., Terada K., Ichikawa J., (1984): Chem. Pharm. Bull., 32, 4566.

Nur A.O and Zhang J.S., (2000): Captopril floating and/or bioadhesive tablets: design and release kinetics. Drug Dev. Ind. Pharm. 26, 965-969.

Preda M. and Leucuta S.E., (2003): Oxpernolol-loaded bioadhesive microspheres: preparation and in vitro/in vivo characterization. J Microencapsul. 20 (6), 777789.

Ruddy S. B., Matuszewska B. K., Grim Y. A., Ostovic D. and Storey D.E., (1999): Int. J. Pharm., 182, 173.

Rupprecht, H., (1990): Progr. Coll. Polym. Sci., 83, 110.

Sato Y., Kawashima Y., Takeuchi H. and Yamamoto H., (2004): In vitro and in vivo evaluation of riboflavin-containing microballoons for a floating controlled drug delivery system in healthy humans, Int. J. Pharm. 275, pp. 97-107.

Shaker A.A., Yamamoto K., El-Sayed A. M., Habib F.S. and Nakai, Y., (1992): Chem. Pharm. Bull., 40, 1289.

Shell J.W., Louie-Helm J. and Markey M., (2003): Extending the duration of drug release within the stomach during the fed mode, US Patent 6,635,280 (October 21).

Sica D.A., Gehr T.W.B. and Ghosh S., (2005): Clinical pharmacokinetics of Losartan. Clin. Pharmacokinet. 44, 797-814.

Signoretti E. C., Dell'Ultri A., De Salvo A. and Donini L., (1986): Drug Dev. Ind. Pharm., 12, 603.

Singh B.M.,. Kim K.H, (2000): Floating drug delivery systems: an approach to oral controlled drug delivery via gastric retention, J. Control. Rel. 63, 235- 259.

Sinha V., Anitha R., Gbosh S., and Kumaria R., (2007): J. Pharm. Sci., 94, 657.

Srinatha A.,. Pandit J.K, (2008): Multi-unit floating alginate system: effect of additives on ciprofloxacin release, Drug Deliv. 15 (7) 471-476.

Streubel A., Siepmann J. and Bodmeier R., (2002): Floating microparticles based on low density foam powder. Int. J. Pharm. 241, 279-292.

Streubel A., Siepmann J. and Bodmeier R., (2006a): Gastroretentive drug delivery systems. Expert Opin. Drug Deliv. 3 (2), 217-233.

Streubel A., Siepmann J. and Bodmeier, R., (2006b.): Drug delivery to the upper small intestine window using gastroretentive technologies. Curr. Opin. Pharmacol. 6, 501-508.

Strubing S., Abboud T., Contri R.V., Metz, H. and Mader K., (2008b): New insights on poly(vinyl acetate)-based coated floating tablets: characterization of hydration and $\mathrm{CO} 2$ generation by benchtop MRI and its relation to drug release and floating strength. Eur. J. Pharm. Biopharm. 69, 708-717.

Strubing S., Metz H. and Mader K., (2008a): Characterization of poly(vinyl acetate) based floating matrix tablets. J. Control. Release 126, 149-155.

Takeuchi A., Nagira S., Yamamoto H. and Kamshima Y., (2005): Int. J. Pharm., 288, 177. 
Torrado S., Prada P. and Torre P.M., (2004): Chitosan-poly(acrylic) acid polyionic complex: in vivo study to demonstrate prolonged gastric retention. Biomaterials 25 (5), 917-923.

Torre P.M. and Torrado S., (2003): Interpolymer complexes of poly(acrylic acid) and chitosan: influence of the ionic hydrogel-forming medium. Biomaterials 24, 1459-1468.

Torre P.M., Torrado G. and Torrado S., (2005): Poly (acrylic acid) chitosan interpolymer complexes for stomach controlled antibiotic delivery. J. Biomed. Mater. Res. B: Appl. Biomater. 72, 191-197.

Wurster D.E., Alkhamis K.A. and Matheson L.E., (2003): Prediction of the adsorption of diazepam by activated carbon in aqueous media, J. Pharm. Sci. 92, pp. 20082016.

Wurster D.E., Alkhamis K.A. and Matheson L.E., (2003): Prediction of the adsorption of diazepam by activated carbon in aqueous media, J. Pharm. Sci. 92, pp. 20082016.

Yuasa H., Takashima Y., and Kanaya Y., (1996): Chem. Pharm. Bull., 44. 1361.

Zuelger S., Fassih, R. and Lippold B.C., (2002): Polymer particle erosion controlling drug release. II. Swelling investigations to clarify the release mechanism. Int. J. Pharm. 247, 23-37.

Zuleger S. and Lippold B.C., (2001): Polymer particle erosion controlling drug release. I. Factors influencing drug release and characterization of the release mechanism. Int. J. Pharm. 217, 139-152.

\footnotetext{
تحسين الاتاحة المعملية لعقار السيليكوكسيب المحمل علي بعض المواد المازة من الكبسولات الطافية

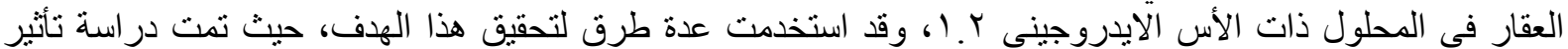

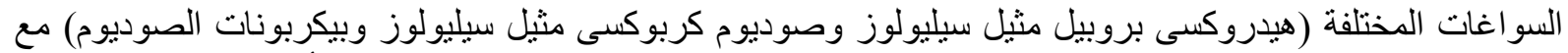

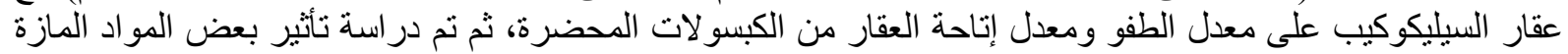

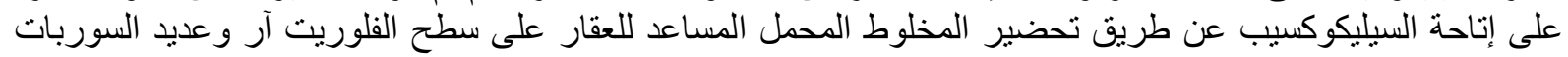

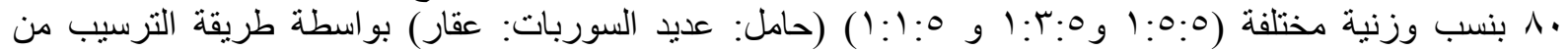

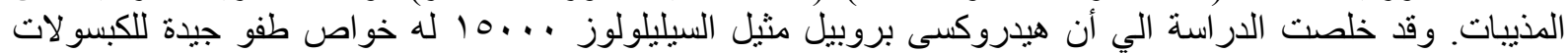

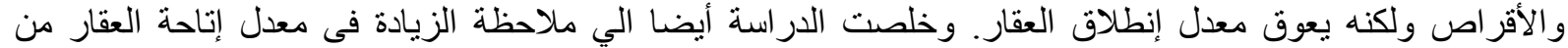

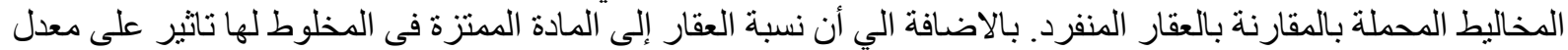

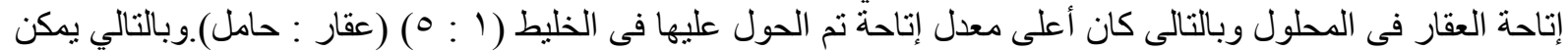

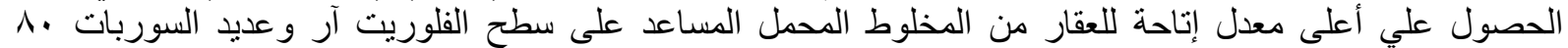

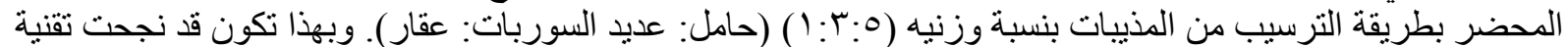

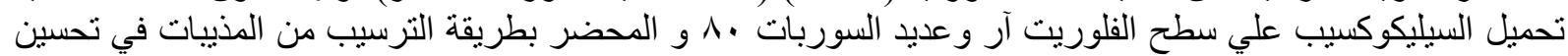
الانطلاق المعملي من الكبسو لات الطافية.
} 